\title{
Local protection against mountain hazards - state of the art and future needs
}

\author{
M. Holub and J. Hübl \\ Institute of Mountain Risk Engineering, University of Natural Resources and Applied Life Sciences, Vienna, Austria
}

Received: 31 October 2007 - Accepted: 15 January 2008 - Published: 15 February 2008

\begin{abstract}
During the last decades, settlement activities increased in European mountain regions. Due to the scarceness of areas suitable for development, residential estates were extended into areas endangered by natural hazards such as mass movements. These settlements generally show a considerable vulnerability to tangible assets.

Integral risk management strategies to reduce the vulnerability to tangible assets are presented for the assessment of such endangered areas. Conventional mitigation and local structural measures are discussed with respect to the necessary delimitation of endangered areas, the preparedness of people and possible financial prevention. According to different natural hazard processes (flash floods with and without bedload transport, debris flows, land slides, rock falls and avalanches) and various structural elements of buildings, a catalogue of local structural measures is presented with respect to occurring process impacts and protection objectives. Thereby, different local structural measures are classified and recommended according to a possible implementation for newly-erected buildings and for upgrading existing buildings, respectively. Based on these recommendations, future needs for a sustainable and comprehensive reduction of risk in settlement areas endangered by mass movements are outlined. Above all, this includes a prescription of building codes and the re-introduction of an obligatory final inspection of buildings.
\end{abstract}

\section{Introduction}

During the last decades, an increasing land-use activity could be observed in European mountain regions. In Austria, settlements have been expanded, leading to extensive land consumption and associated population growth. Since the

Correspondence to: M. Holub

(markus.holub@boku.ac.at) 1970s, the average useable living space rose from $22 \mathrm{~m}^{2}$ per person in 1972 to $38 \mathrm{~m}^{2}$ in 2001 (Statistik Austria, 2004). As a major part of Austria is located in mountain areas above $1000 \mathrm{~m}$ a.s.l. (approx. 36\% of Austria's territory; approx. $19 \%$ of Austria's territory is located higher than $1500 \mathrm{~m}$ a.s.l.), areas suitable for permanent settlement are limited (see Fig. 1). In the entire country, $37.2 \%$ of the whole area is suitable for permanent settlement and associated economic activities, while in some Federal States, the values remain noticeably below one third of the area. Due to this scarcity, commercial parks and particularly vulnerable infrastructure has been extended into areas which are endangered by natural hazards such as mass movements and avalanches.

Consequently, an increase in losses due to hazard processes is often claimed in recent years and can be mostly explained by an increase of property values in endangered areas (Munich Re, 2007). However, these statements have hardly been quantified. Until now, only few studies addressed the development of losses due to natural hazards in the Alps (SLF, 2000; Jóhannesson and Arnalds, 2001; Nöthiger et al., 2002; Fuchs and Bründl, 2005) and in Austria (EmbletonHamann, 1997; Luzian, 2000; Oberndorfer et al., 2007).

In Austria, strategies to prevent or to reduce the effects of natural hazards in areas of settlements and economic activities have a long tradition. Apart from early attempts for the local protection of settlements tracing back in the mediaeval times, official authorities were only founded in 1884 (Länger, 2003) based on a first legal regulation (Österreichisch-Ungarische Monarchie, 1884). In the second half of the 19th and in the early 20th century, protection against natural hazards was mainly organised by implementing permanent measures in the upper parts of the catchments to retain solids from erosion and in the release areas of avalanches. These measures were supplemented by silvicultural efforts to afforest high altitudes. Since the 1950s such conventional mitigation concepts - which aimed

Published by Copernicus Publications on behalf of the European Geosciences Union. 


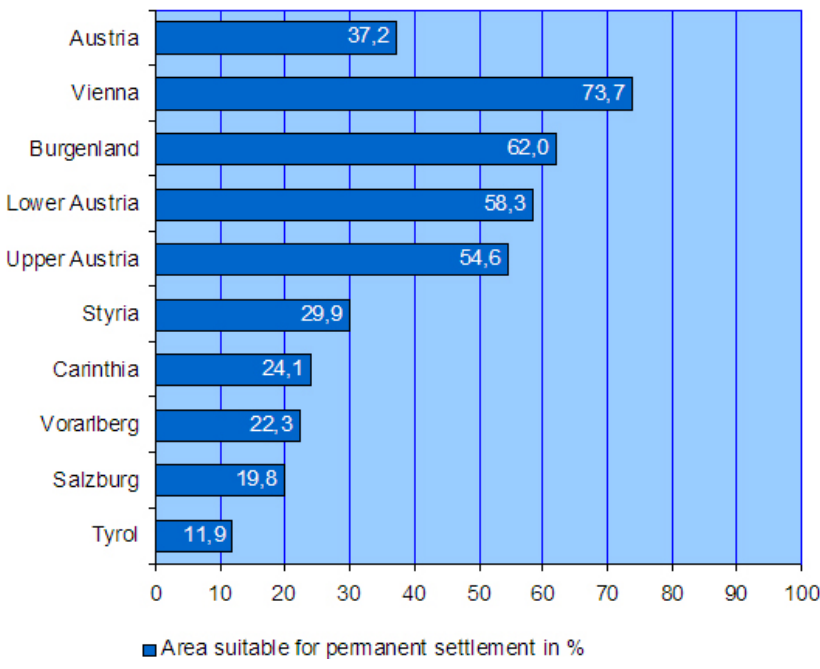

Fig. 1. Percentage of area suitable for permanent settlement in Austria and in the Federal States (BEV, 2004).

at decreasing both, the intensity and the frequency of events were increasingly complemented by more sophisticated technical mitigation measures. Until the 1970s, mitigation concepts mainly aimed at the deflection of hazard processes into areas not used for settlements. In 1975, the Forest Act was introduced, legally prescribing fundamentals in dealing with natural hazards in Austria (Republik Österreich, 1975). Additional legal regulations for torrent and avalanche control as well as hazard mapping were implemented in 1976 (Republik Österreich, 1976).

Consecutively to the development of land-use planning in the mid-1970s, hazard maps were introduced as a passive mitigation measure to prevent the development of settlement activities in endangered areas (Länger, 2005). Hazard maps, expected to be implemented area-wide across Austria by 2010 , are supplemented by building codes in areas with less hazard impact, and serve as a basis for integral risk management strategies. As a result, hazard processes are no longer solely deflected; conversely, a combination of diverse active and passive mitigation measures is applied to prevent damage to buildings, infrastructure and persons. This combination includes conventional technical structures to influence the natural process as well as local structural measures to reduce the process impact on values at risk.

However, little information is available on local structural protection measures so far, in particular with respect to different types, designs and materials used. The aim of the following sections is to partly close this gap by (1) presenting the concept of local structural protection within the framework of integral risk management and (2) providing a catalogue of local structural measures used in Austria to protect buildings as well as infrastructure and lifelines.
Table 1. Technical protection measures according to their location of implementation.

\begin{tabular}{lccc}
\hline & Catchment & Channel/Track & Deposition area \\
\hline Drainage & $\mathbf{X}$ & & \\
Stabilising structures & $\mathbf{X}$ & $\mathbf{X}$ & \\
Consolidating structures & & $\mathbf{X}$ & \\
Deflecting structures & & $\mathbf{X}$ & $\mathbf{X}$ \\
Breaking structures & & & $\mathbf{X}$ \\
Filtering structures & & & $\mathbf{X}$ \\
Retaining structures & & & $\mathbf{X}$ \\
Deposition areas/basins & & $\mathbf{X}$ & $\mathbf{X}$ \\
Channel enlargement & & & $\mathbf{X}$ \\
\hline
\end{tabular}

\section{Conventional mitigation within the framework of in- tegral risk management}

In the Republic of Austria, conventional mitigation of natural hazards can be traced back to the 1890s, when the French system of forest-technical torrent and avalanche control was adopted. Watershed management measures, forest-biological and soil bio-engineering measures as well as technical measures (construction material: timber and stone masonry) had been implemented. Thus, conventional mitigation concepts - which influence both, the intensity and the frequency of events - only consider technical structures within the catchment, along the channel system or track and in the deposition area. According to the approach of disposition management (reducing the probability of occurrence of natural hazards) and event management (interfering the transport process of the hazard itself), a wide range of technical measures is applicable (Hübl and Fiebiger, 2005; see Table 1).

Conventional technical measures are not only very costintensive in construction, moreover, they interfere with the ecology of a torrent as well as with the adjacent landscape (e.g. Bĕlský and Jařabáč, 2004; Mayer, 2004; Rudolf-Miklau and Patek, 2004). Additionally, because of a limited lifetime and therefore an increasing complexity of maintenance in high-mountain regions, future feasibility of technical structures is restricted due to a scarceness of financial resources provided by responsible authorities (Weinmeister, 1994). If maintenance is neglected, mitigation measures will become ineffective and can even increase the catastrophic potential of natural hazards (Aulitzky, 1970).

Since conventional technical measures do neither guarantee reliability nor complete safety (Schmid, 2005), a residual risk of damage to buildings, infrastructure and harm to people remains (Fell, 1994; BMLFUW, 2006). Even if such mitigation measures may reduce short-term losses, the long term vulnerability might increase due to an enhanced attraction of "secured" areas for settlement activities and institutional investors (Mileti and Myers, 1997).

Experiences from the last years suggested that values at risk and spatial planning should be increasingly considered 
Table 2. Compilation of definitions with respect to diverse mitigation measures.

\begin{tabular}{ll}
\hline Active mitigation measures & $\begin{array}{l}\text { Initiation, transport or deposition of mass movements can be influenced by active } \\
\text { mitigation measures. The change of characteristics of magnitude and frequency can } \\
\text { be achieved either by influencing the probability of occurrence of a hazardous event } \\
\text { (disposition management), or by manipulating the hazardous process itself (event } \\
\text { management) (Hübl and Fiebiger, 2005). } \\
\text { Active countermeasures should reduce the consequences of the potential hazard. }\end{array}$ \\
\hline Passive mitigation measures & $\begin{array}{l}\text { Passive mitigation measures are based on the principle of spatial separation of the } \\
\text { endangered people and objects from the hazardous area (Wilhelm, 1997). } \\
\text { A reduction of potential loss and decrease of vulnerability should be achieved by } \\
\text { preventive measures (spatial planning, land-use) and event response (immediate ac- } \\
\text { tions in case of an (expected) event). }\end{array}$ \\
\hline Structural mitigation measures & \begin{tabular}{l} 
Structural measures include all physical measures used to mitigate natural hazards. \\
\hline Non-structural mitigation measures
\end{tabular} \\
$\begin{array}{l}\text { Non-structural mitigation measures typically concentrate on identifying hazard- } \\
\text { prone areas and limiting their use temporarily or permanently. Further forestal mea- } \\
\text { sures can be seen as non-structural measures. } \\
\text { Non-structural countermeasures are very site-specific and they greatly depend on } \\
\text { the organizational and legal structures in each country. }\end{array}$ \\
$\begin{array}{l}\text { Permanent measures comprehend durable technical and forestal measures as well as } \\
\text { land-use planning. Further information of population is subsumed. }\end{array}$ \\
\hline Permanent mitigation measures \\
$\begin{array}{l}\text { Temporary measures are adjusted to a certain point of time and the hazard potential } \\
\text { of a location. These measures are executed spontaneously. } \\
\text { Usually they complete or substitute the permanent measures with respect to an in- } \\
\text { creased economic efficiency. }\end{array}$ \\
\hline
\end{tabular}

within the framework of natural hazard reduction (Kanonier, 2006). To meet this goal, integral risk management strategies seem to be a valuable instrument to reduce the susceptibility of buildings and infrastructure to natural hazards and to develop strategies for a strengthened resistance.

The framework of integral risk management requires a combination of active and passive measures to reduce the impact of natural hazard processes. Thereby, active measures are applied to mitigate the process and passive measures are based on the principle of a spatial separation of values at risk from endangered areas (Hübl and Steinwendtner, 2000). However, a review of existing literature had shown that active and passive measures are not defined in a unique system until now, since these terms have different meanings depending on the different mitigation philosophies in individual countries. Not only "active" and "passive" mitigation measures are used as customary terms in dealing with natural hazards, further well-established terms such as "permanent", "temporary", "structural" and "non-structural" measures can be found in the literature. For a clarification, definitions widely used in European mountain areas are shown in Table 2.

Following these definitions, mitigation measures are categorised applying a matrix presented in Table 3. As a result, active permanent mitigation measures, such as technical measures and forestal measures, can be distinguished
Table 3. Categories of mitigation measures.

\begin{tabular}{lll}
\hline & Active & Passive \\
\hline Permanent & Soil bio-engineering & Spatial planning and land-use \\
& Forestal measures & Hazard mapping \\
& Technical measures & Local structural measures \\
Temporarily & Immediate measures & Information and warning \\
& & Exclusion zones and evacuation \\
\hline
\end{tabular}

from passive permanent spatial planning activities and landuse regulations. Permanent measures are supplemented by temporary measures, such as immediate support (active) and evacuation (passive). With respect to risk management strategies, a combination of active and passive measures and permanent and temporal measures is used for an optimised and cost-efficient prevention of damage (e.g. Leitgeb and Rudolf-Miklau, 2004; Fuchs et al., 2007a). Thereby, damage is - apart from definitions in social sciences, where negatively evaluated consequences or effects of an event are subjectively and normatively rated - considered as quantifiable mathematical number, e.g. in terms of monetary units (Berg, 1994). 
Table 4. Distribution of damage at the building itself and at interior decoration (adopted from Egli, 2002a).

\begin{tabular}{ll}
\hline Damage at the building itself & Damage at interior decoration \\
\hline Walls, ceilings and their panelling (36\%) & Furniture (40\%) \\
Floor and floor covering (27\%) & Fixtures (40\%) \\
Heating system (27\%) & Doors and electrical equipment $(20 \%)$ \\
Electric wires and windows (10\%) & \\
\hline
\end{tabular}

Risk resulting from natural hazards is defined as a function of the probability of a hazard process and the related extent of damage (Eq. 1). In accordance with the definition of (United Nations, 2004), specifications for the probability of the defined scenario $\left(p_{S i}\right)$, the value of the object affected by this scenario $\left(A_{O j}\right)$, the probability of exposure of object $j$ to scenario $i\left(p_{O j}, S i\right)$, and the vulnerability of object $j$ in dependence on scenario $i\left(v_{O j, S i}\right)$ are required for the quantification of risk $\left(R_{i, j}\right)$.

$$
R_{i, j}=f\left(p_{S i}, A_{O j}, v_{O j, S i}, p_{O j, S i}\right)
$$

By risk management strategies, population vulnerability can be reduced and the susceptibility of values at risk can be minimised considering the following fundamental issues (Habersack et al., 2004; Fuchs et al., 2007b):

\section{Spatial precaution (risk prevention)}

Areas, which are permanently or at least temporarily exposed to natural hazards, are to be kept free from settlements (Roy et al., 2003; Hooijer et al., 2004). This fundamental statement is mirrored by the current legislation in Austria, where areas of permanent danger due to natural processes have to be delimited by hazard maps (Republik Österreich, 1976). During spatial planning activities, these areas should not be allotted for development. However, alternative utilisation, such as for agricultural purpose or leisure activities remain possible (Hattenberger, 2006; Kanonier, 2006). Spatial planning (competence of the Federal States), land-use planning (competence of the municipalities which act at the same time as building authority), and hazard mapping (competence of the Federation, conducted by the Austrian Forest Technical Service of Torrent and Avalanche Control; see Appendix A) are common tools. For the latter, intensity maps, synoptically hazard maps, risk maps and protection deficit maps are required as an essential basis for a sustainable management of natural hazards (Borter, 1999; Egli, 2000a).

\section{Structural precaution (risk reduction)}

Damage to objects without structural precautions is evenly distributed to the building and the interior, such as furniture and content (see Table 4). The damage costs

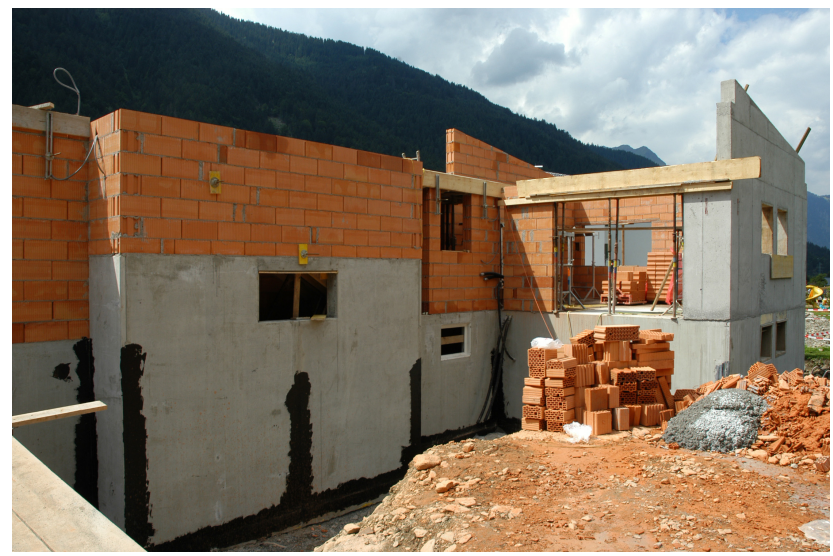

Fig. 2. Brick walls reinforced by ferro-concrete components to strengthen the building's resistance.

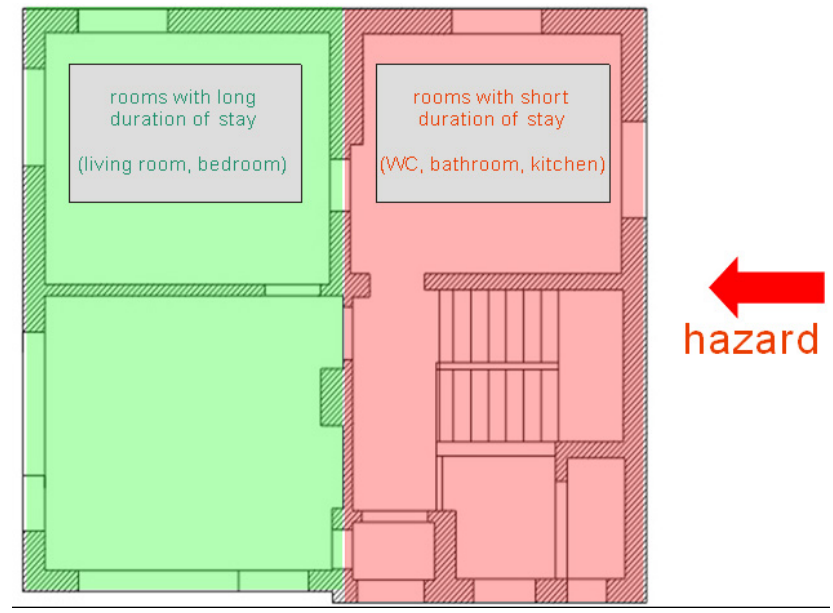

Fig. 3. Distribution of the different rooms according to occupancy time and the hazard potential.

easily doubles or triples if an oil tank bursts by buoyancy and leaks oil.

Besides conventional technical mitigation measures, structural precaution is achieved by an adapted construction design and the appropriate use of an object. Structural precaution is the main application domain for local structural measures, since the individual vulnerability of buildings can be fundamentally decreased by strengthening e.g. brick walls with reinforced concrete components (Fig. 2), and/or the adopted interior design of the different rooms according to occupancy time and hazard potential. Figure 3 provides a model for such adopted design; the sleeping room is located opposite the hazard impact whilst the bathroom is located more hazard-exposed. A well organised utilisation of the rooms can influence the vulnerability and as a result the risk considerably (Fell, 1994; Fell and Hartford, 1997). 


\section{Behavioural precaution (risk reduction)}

In general, the triggering mechanisms of mountain hazards initiate processes with considerable high transport velocities. As a consequence, possibilities of forecasting and warning are limited due to a relatively short time period between cause and effect (see Table 5). Thus, preparedness for such events is closely linked to peoples' behaviour, in particular with respect to evacuation and sheltering (Fell and Hartford, 1997). Behavioural precaution is a risk reduction principle addressing concrete action before, during and after a hazardous event. However, top-down approaches concerning appeals and information are usually not well received; on the other hand, the responsibility for possible deficits is regularly attributed to the institutional obligations of public authorities in the aftermath of an event. If obligation to concrete precautions by the authorities is not supported by noticeable incentives, such actions can only be considered as an offer to self-motivated people (Ita and Giller, 2006). As a long term objective, shaping the opinion of people to assume personal responsibility for natural hazard mitigation should be achieved. Furthermore, there is a call for voluntary contributions to the prevention of disasters (Patek, 2003).

\section{Institutional precaution (risk transfer)}

Transferring risks to a broader community is usually achievable through products sold on the insurance market. However, any insurance to cover losses from natural hazards is optional in Austria. Apart from the inclusion of damage resulting from hail, pressure due to snow load, rock fall and sliding processes in an optional storm damage insurance, no standardised product is currently available on the national insurance market. Moreover, the terms of business of this storm damage insurance explicitly exclude coverage of damage due to avalanches, floods and inundation, debris flows, earthquakes and similar extraordinary natural events (Schieferer, 2006). As a result, each citizen is responsible for individual private financial reserves to cover losses resulting from natural hazards, which might increase the individual vulnerability. Compulsory elementary insurance is only recently debated, but could transfer the risk by shifting losses to a broader community (UngernSternberg, 2004).

If the terms "structural precaution" and "personal responsibility" are combined for a mental exercise, "local structural measures" appear as the logical result. However, since local structural measures have to be regarded as personal (private) precaution, it is the individual responsibility to implement such structures. Individual responsibility ranks among the basic pillars of the civil defence system. Therefore, adequate information and an appropriate practical implementation in the private sec-
Table 5. Velocity of mass movements and resulting advance warning time.

\begin{tabular}{lll}
\hline Mass movement & $\begin{array}{l}\text { Maximum velocity } \\
{[\mathrm{km} / \mathrm{h}]([\mathrm{m} / \mathrm{s}])}\end{array}$ & Advance warning time \\
\hline Flash flood & $20(5)$ & Seconds to minutes \\
Debris flow & $40(10)$ & Seconds to minutes \\
Spontaneous land slide & $4(1)$ & Seconds to minutes \\
Permanent land slide & $1-1000 \mathrm{~mm} / \mathrm{a}$ & $\begin{array}{l}\text { Months to years } \\
\text { Rock fall }\end{array}$ \\
$\begin{array}{l}\text { Dense avalanche } \\
\text { Powder avalanche }\end{array}$ & $40-140(30-40)$ & Seconds \\
\hline
\end{tabular}

tor are particularly important to achieve a higher level of personal precaution (Ita and Giller, 2006).

\section{Local protection measures - fundamentals and effects}

The principles of planning and implementation of local structural measures to reduce vulnerability against natural hazards are neither highly sophisticated nor very innovative. However, the performance of local structural measures often is neglected or even ignored following the proverb that cheap solutions cannot be effective. Generally, local structural measures are "the afterthought of a tragedy rather than a forethought of prevention" and are "developed based on individual experiences more than scientific knowledge" (IBHS, 2005). Besides, in relation to the potential damage caused by natural hazards, the construction of local structural measures seems to be reasonable, in particular if renewal or reconstruction is planned (FEMA, 1998).

\subsection{Fundamentals}

Some basic principles should be considered for the implementation of local structural measures:

1. Knowledge of the interactions between all the possible hazard processes within the area concerned is required.

It is insufficient to refer only on the most probable transport process, rather than to consider all possible hazard processes and the inherent interactions and interdependencies (multi-hazard- and multi-risk-approach, respectively).

2. Spatial measures should be preferred to structural measures.

The most effective way to avert the impact of natural hazards to damage potential is to keep the affected areas clear of values at risk. Therefore, non-structural mitigation measures - such as land-use planning activities - should take priority over other mitigation concepts. Moreover, the implementation of local structural 
Table 6. The effect of different strategies to avoid water intrusion into buildings (adopted from Egli, 2002a, b).

\begin{tabular}{ll}
\hline Local structural measure & Efficiency \\
\hline Deflection of floods & $60-80 \%$ \\
Elevated construction & almost $100 \%$ \\
Sealing of the building's openings & $50-85 \%$ \\
Sealing of the building's openings in combination with deflection & almost $100 \%$ \\
Water resistant interior design & $10-35 \%$ \\
Adopted use of the building & $30-40 \%$ \\
\hline
\end{tabular}

measures usually involves - occasionally considerable - costs. Consequently, the upgrading of existing objects with such measures might be rather unprofitable with respect to the required high expenditures. Even if cost-benefit ratios of local structural measures suggest an economic efficiency, the implementation might fail since the construction costs occur in the present while the possible benefits arise in the future. Although economically considered by discount rates, this does not encourage private initiatives for the implementation of local structural protection measures (Ita and Giller, 2006).

3. Permanent measures should be preferred to mobile equipment.

As mountain hazard processes are usually characterised by high transport velocities, lead time for reaction (if early warning systems are installed) might be very short. Thus, mobile mitigation measures cannot provide the same safety level than fix installed protective systems since they need a certain amount of time for installation. In particular, the required installation time can increase considerably if the elements of the mobile protective system are not disposable directly at the endangered object and/or the operator is not regularly trained in setting up the system.

4. Damage to third parties is not acceptable; hence, local structural protection must not cause negative impacts to adjacent or downstream riparian owners' values at risk.

Following disastrous losses, persons concerned are typically willing to implement local structural measures. As a result, these measures are often installed in individual responsibility neglecting any integrated concept performed by the authorities in charge. In doing so, uncoordinated mitigation results within the area affected by the hazard process, and possible future losses are shifted further downwards the catchment (e.g. massive concrete walls which deflect the runoff and the sediments to the adjacent property).

To conclude, the apparent objectives of local structural measures include the limitation of loss potential, damage to third parties, and damage to the environment (Egli, 2002a). Knowledge on the hazard processes and the related impacts, the feasibility of individual local structural measures as well as the effect of the combination of individual measures are essential for the effectiveness of local protection measures.

\subsection{Effects}

It seems to be obvious that local structural measures reduce the vulnerability of buildings considerably. However, since data related to the effects of process impacts towards buildings are rare, and in particular a possible reduction of impacts due to local structural measures has not been quantified satisfyingly so far, the decrease of vulnerability has hardly been measured until now (Kreibich et al., 2005; Grothmann and Reusswig, 2006).

Nevertheless, with respect to inundations and flooding, local structural measures are found to be effective in decreasing vulnerability, in particular if flood levels are below two metres (Egli, 2002a, b) and if static flood intensities are small, respectively (Kreibich et al., 2005). With respect to dynamic flooding, Kimmerle (2002) had proven that buildings with local protection measures suffered less damage than unprotected ones, and concluded that particular combinations of different local structural measures are effective in sheltering values at risk from impacts due to torrential floods. Design and performance are the most important issues considering the efficiency of local structural measures. Consequently, strategies of reducing losses show different levels of effectiveness with respect to different types of measures (see Table 6).

These findings support the results presented in Fuchs et al. (2007b) on the effects on vulnerability depending on whether or not bedload penetrated a building located on a torrent fan. In particular with respect to low and medium debris flow intensities, local structural measures such as deflection walls and coverings of building openings seem to be an appropriate tool to decrease vulnerability.

Local structural protection can be either performed as enclosing structure or as structure directly connected to the building. Measures surrounding the object at risk seem to be more effective since they prevent immediate impacts on the 


\begin{tabular}{|c|c|c|c|c|}
\hline \multirow{3}{*}{$\begin{aligned} \mathscr{O} & =\text { low resistance } \\
\ddot{-} & =\text { average resistance } \\
\ddot{*} & =\text { high resistance }\end{aligned}$} & \multirow{2}{*}{\multicolumn{4}{|c|}{ Resistance to }} \\
\hline & & & & \\
\hline & Avalanche & Debris flow & Rock fall & Water (Flood) \\
\hline \multicolumn{5}{|c|}{ Construction material respectively embodiment } \\
\hline Loose fill material - soil & $\ddot{*}$ & 9 & $\ddot{-}$ & $\ddot{-}$ \\
\hline Stone masonry & $\ddot{-}$ & $\ddot{-}$ & $\ddot{-}$ & $\ddot{*}$ \\
\hline Masonry & $\ddot{-}$ & $\ddot{-}$ & $\ddot{-}$ & 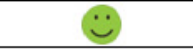 \\
\hline Concrete & $\ddot{\theta}$ & $\ddot{-}$ & 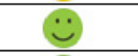 & 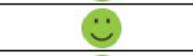 \\
\hline Reinforced concrete & $\ddot{\theta}$ & $\ddot{*}$ & $\ddot{\theta}$ & $\ddot{r}$ \\
\hline Timber $\left.{ }^{*}\right)$ & $\ddot{P}$ & $\ddot{P}$ & $\ddot{*}$ & $\ddot{-}$ \\
\hline Stone & $\ddot{-}$ & $\ddot{-}$ & $\ddot{-}$ & $\ddot{*}$ \\
\hline Steel & $\ddot{r}$ & $\ddot{*}$ & $\ddot{r}$ & 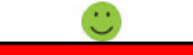 \\
\hline \multicolumn{5}{|c|}{ Wall } \\
\hline Lime sand brick & $\ddot{-}$ & 2 & 2 & $\ddot{r}$ \\
\hline Fired solid brick & $\ddot{-}$ & $\ddot{-}$ & $\ddot{-}$ & $\ddot{*}$ \\
\hline Vertically perforated brick & $\ddot{-}$ & $\ddot{-}$ & $\ddot{-}$ & $\ddot{-}$ \\
\hline Clinker & $\ddot{-}$ & $\ddot{-}$ & $\ddot{-}$ & $\ddot{\theta}$ \\
\hline Concrete & $\ddot{*}$ & 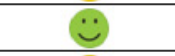 & $\ddot{\theta}$ & $\ddot{*}$ \\
\hline Aerated concrete (gas concrete) & 2 & $\ddot{-}$ & $\ddot{-}$ & $\ddot{-}$ \\
\hline Timber $\left.{ }^{*}\right)$ & $\ddot{-}$ & $\ddot{-}$ & $\ddot{-}$ & $\ddot{-}$ \\
\hline Timber block construction & $\ddot{\theta}$ & $\ddot{*}$ & $\ddot{\theta}$ & $\ddot{-}$ \\
\hline Timber framing - prefabricated house & 2 & 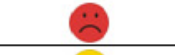 & 2 & $\ddot{-}$ \\
\hline Reinforced concrete elements - prefabr. house & $\ddot{-}$ & $\ddot{-}$ & $\ddot{-}$ & $\ddot{*}$ \\
\hline Glass brick & $\ddot{-}$ & $\ddot{-}$ & $\ddot{-}$ & 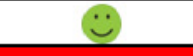 \\
\hline \multicolumn{5}{|c|}{ Window } \\
\hline Timber") & $\ddot{\theta}$ & $\ddot{\theta}$ & $\ddot{-}$ & $\ddot{-}$ \\
\hline Plastics & $\ddot{-}$ & $\ddot{-}$ & $\ddot{-}$ & $\ddot{\ddot{\theta}} \ddot{-}$ \\
\hline Aluminium & $\ddot{\theta}$ & $\ddot{P}$ & $\ddot{*}$ & $\ddot{*}$ \\
\hline Galvanised steel & $\ddot{r}$ & (i) & $\ddot{r}$ & 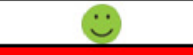 \\
\hline \multicolumn{5}{|c|}{ Windowsill } \\
\hline Marble & $\ddot{\theta}$ & $\ddot{-}$ & $\ddot{-}$ & 8 \\
\hline Other natural stone & $\ddot{*}$ & $\ddot{-}$ & $\ddot{-}$ & $\ddot{*}$ \\
\hline Timber") & $\ddot{*}$ & $\ddot{-}$ & $\ddot{-}$ & $\ddot{-}$ \\
\hline Coated aluminium and metal & $\ddot{*}$ & 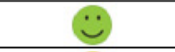 & $\ddot{\theta}$ & $\ddot{\theta}$ \\
\hline Sandstone & $\ddot{*}$ & $\ddot{-}$ & $\ddot{-}$ & 8 \\
\hline Schist & $\ddot{*}$ & $\ddot{-}$ & $\ddot{-}$ & $\ddot{-}$ \\
\hline \multicolumn{5}{|c|}{ Door } \\
\hline Wooden doorframe / timber set & $\ddot{-}$ & $\ddot{-}$ & $\ddot{-}$ & 2 \\
\hline Metallic door frame & $\ddot{\theta}$ & $\ddot{\theta}$ & $\ddot{\theta}$ & $\ddot{v}$ \\
\hline Wooden door") & $\ddot{\theta}$ & 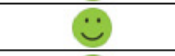 & $\ddot{\theta}$ & 2 \\
\hline Metallic door (high quality steel) & $\ddot{\theta}$ & 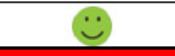 & (i) & $\ddot{r}$ \\
\hline \multicolumn{5}{|c|}{ Stair } \\
\hline Concrete & $\ddot{\theta}$ & $\ddot{v}$ & $\ddot{*}$ & $\ddot{*}$ \\
\hline Solid wood & $\ddot{-}$ & $\ddot{-}$ & $\ddot{-}$ & $\ddot{-}$ \\
\hline Galvanised steel construction & $\ddot{-}$ & $\ddot{-}$ & $\ddot{-}$ & $\ddot{\theta}$ \\
\hline Massive stair in natural stone & $\ddot{-}$ & $\ddot{-}$ & $\because-$ & 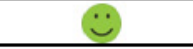 \\
\hline
\end{tabular}

Fig. 4. Resistance of conventional construction materials to natural hazards (modified from Strauss, 2006, personal communication). 
Table 7. Classification of local structural measures.

\begin{tabular}{lll}
\hline Criteria & Classes & Description \\
\hline Transport process & $\begin{array}{l}\text { (Flash) flood - debris flow, land slide - } \\
\text { rock fall - avalanche }\end{array}$ & $\begin{array}{l}\text { Different transport processes represent } \\
\text { different impacts. }\end{array}$ \\
\hline Effective period & Permanent - temporarily & $\begin{array}{l}\text { Local structural protection can be either } \\
\text { installed as a permanent device or can } \\
\text { consist out of mobile modules which are } \\
\text { installed only for a certain time after an } \\
\text { early warning. }\end{array}$ \\
\hline Location of local structural measures & $\begin{array}{l}\text { Directly connected to the building - en- } \\
\text { closing the building }\end{array}$ & $\begin{array}{l}\text { Local structural protection can be either } \\
\text { performed as enclosing structure or as } \\
\text { structure directly connected to the build- } \\
\text { ing. }\end{array}$ \\
\hline Construction type & $\begin{array}{l}\text { New building - upgrade of an existing } \\
\text { building }\end{array}$ & $\begin{array}{l}\text { Different local structural measures show } \\
\text { different feasibility due to the construc- } \\
\text { tion of new buildings or renovation of ex- }\end{array}$ \\
& isting ones. \\
\hline Construction materials & $\begin{array}{l}\text { Soil - timber - steel - brick (masonry) } \\
\text { concrete - reinforced concrete }\end{array}$ & $\begin{array}{l}\text { Considering the transport process and its } \\
\text { impact, different construction materials } \\
\text { show different performances. }\end{array}$ \\
\hline
\end{tabular}

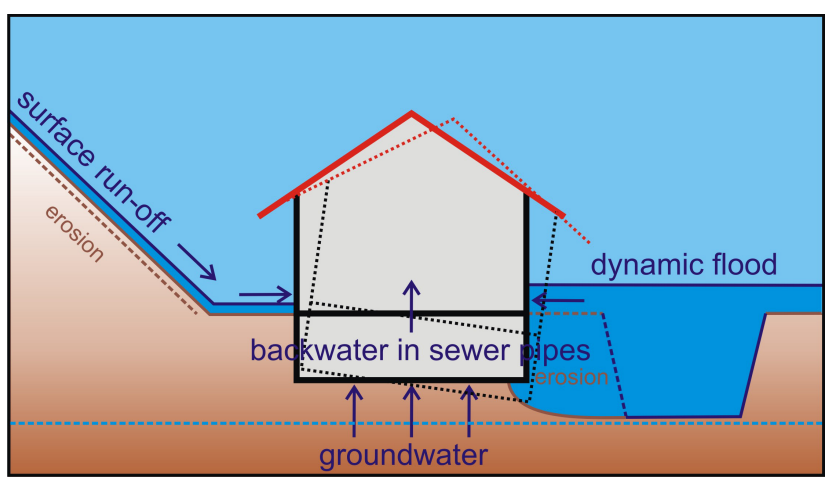

Fig. 5. Damage patterns due to static and dynamic floods.

building shell, while structures directly implemented at the building shell are generally less space-consuming. However, a combination of measures is anticipated to increase the level of safety. Apart from engineering foci presented above, it has to be emphasised that local structural measures generally fit better in the landscape than traditional mitigation measures. Even if a quantification of this effect is outstanding, measures protecting individual objects usually consist from smaller structures which could either be integrated harmonically into the building's appearance or which are generally not visible to untrained eyes.

\section{Catalogue of local structural measures}

The following catalogue of local structural measures used in European alpine regions represents an overview of existing and well-established protective techniques, and aims at increasing the resistance of buildings planned and constructed in the future. Consequently, the catalogue might be a valuable tool to decrease the susceptibility to loss resulting from natural hazards - in particular for consultants and practitioners. Taking the classification of local structural measures into account, some fundamentals should be considered before implementing the necessary structural adaptation.

\subsection{Classification of local structural measures}

Local structural measures can be distinguished and classified in various ways, i.e., according to the applicability for protection against the hazard process, the location with respect to the protected object, as well as the type of construction and material used; a further differentiation is possible whether the local structure is of permanently or temporarily use, see Table 7. Considering the possible impacts of natural hazards, different construction materials show different performance and resistance. In Fig. 4, a list of conventional construction materials regularly used in the building industry is presented, and their suitability for resisting various process impacts is shown. If the hazardous processes endangering an object at risk are assessed, these tables can be used to determine relevant impacts on the objects. Moreover, the main protection 


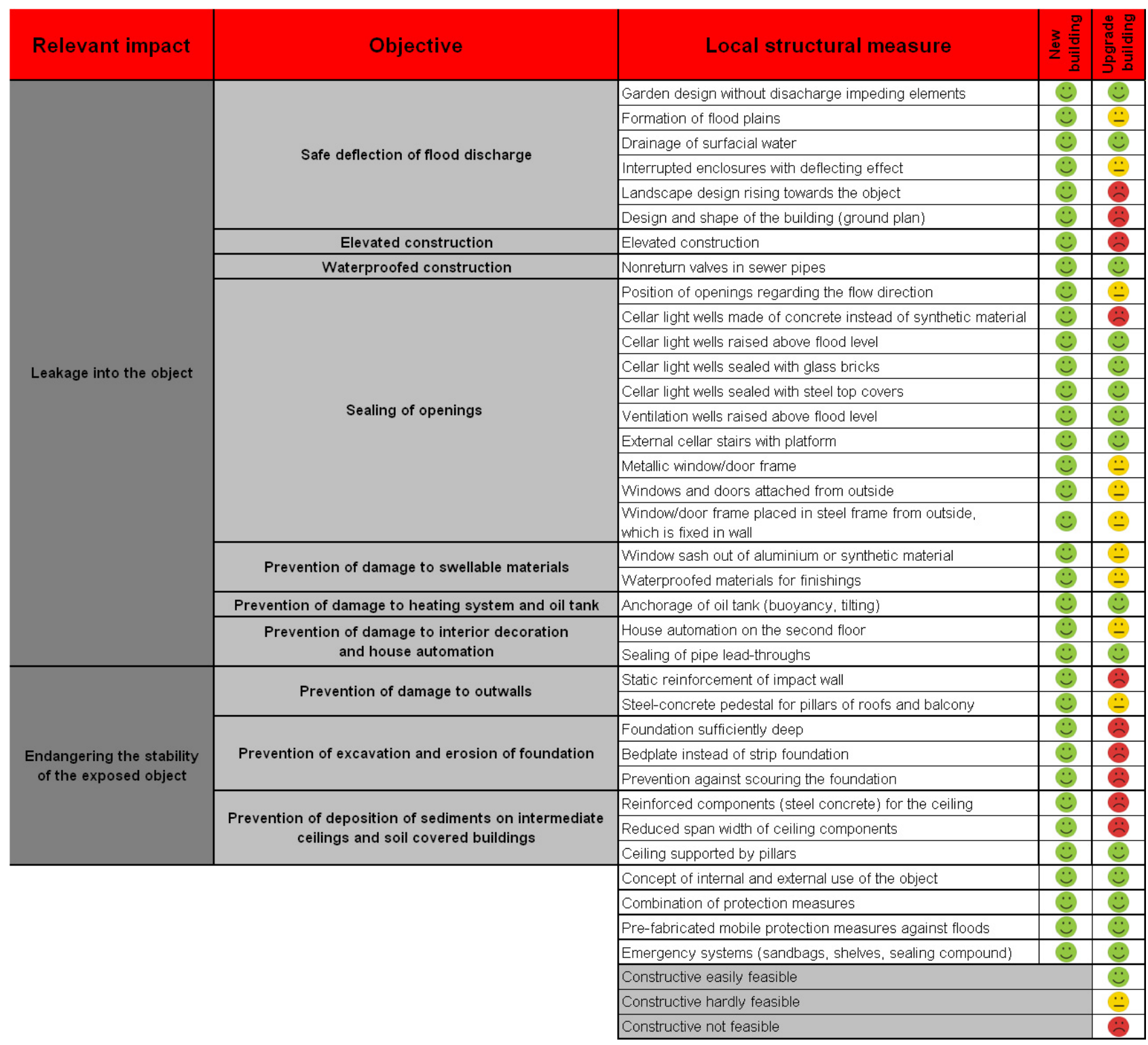

Fig. 6. Local structural measures for new buildings as well as for an upgrade of existing objects with respect to possible impacts of floods.

objectives and the possible local structural measures are described.

4.2 Catalogue of local structural measures - static and dynamic floods, and fluvial transport of bedload

Impacts originating from static or dynamic flood as well as from extraordinary surface runoff, accompanied by transport of solids, endanger the stability of the building (see Fig. 5). The major processes include groundwater buoyancy and erosion processes, apart from the possible intrusion of water and solids through the building openings and the sewage system, the latter causing damage to the interior of the buildings. Several local structural measures are possible, as shown in
Fig. 6. Considering the catalogue of local structural measures to protect buildings against floods, widely-used examples of protection measures, such as elevated constructions and sealed openings, are presented in Figs. 7-10. For the erection of new buildings, the terrain can be elevated above the flood level, which results in an overall decrease in retention area from an integrated spatial point of view (Fig. 7). If structural re-calculation is possible, the ground floor can be built on stilts and elevated above flood level (Fig. 8). The upgrade of existing buildings often requires slightly different measures, such as the enhancement of light wells (Fig. 9) and basement stairs (Fig. 10) above flood level. 


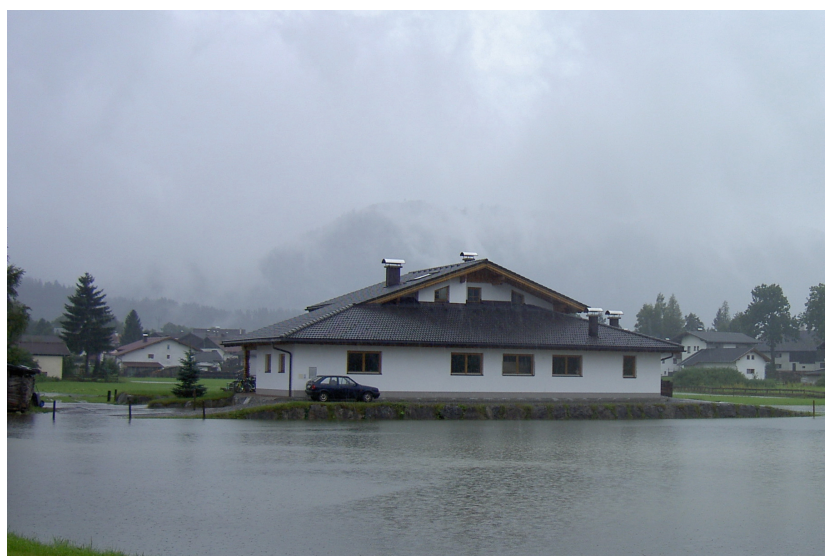

Fig. 7. New building: Object built on altered (elevated) terrain (courtesy of: die.wildbach, 2005).

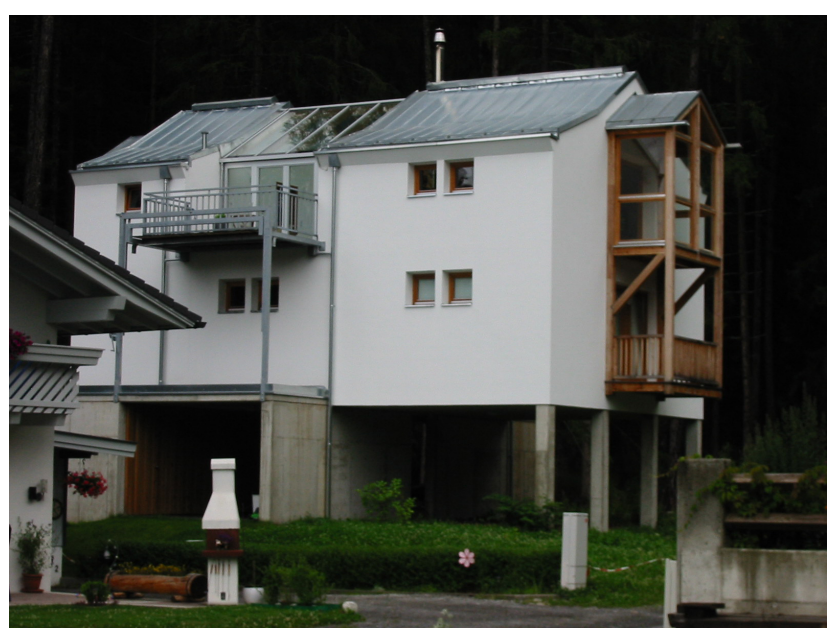

Fig. 8. New building: Object built on stilts (courtesy of: Fuchs, 2007).

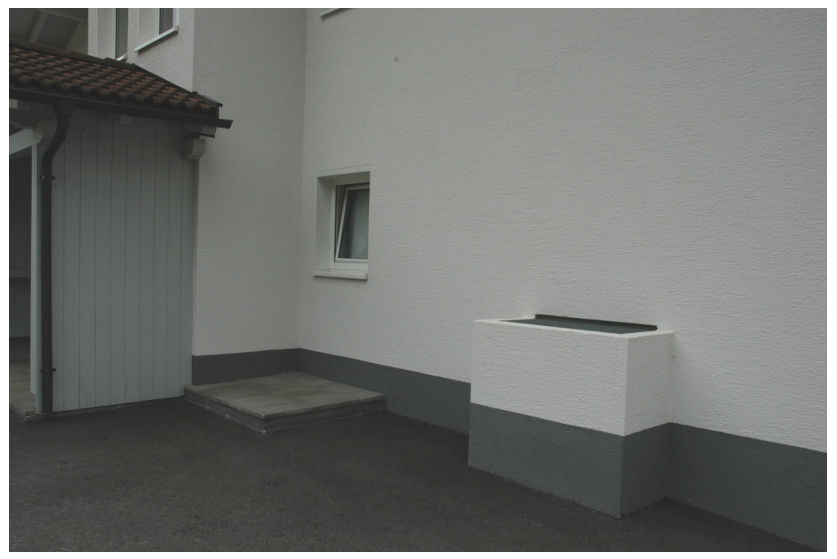

Fig. 9. New building and upgrade: Enhancement (raising) of light wells above flood level.

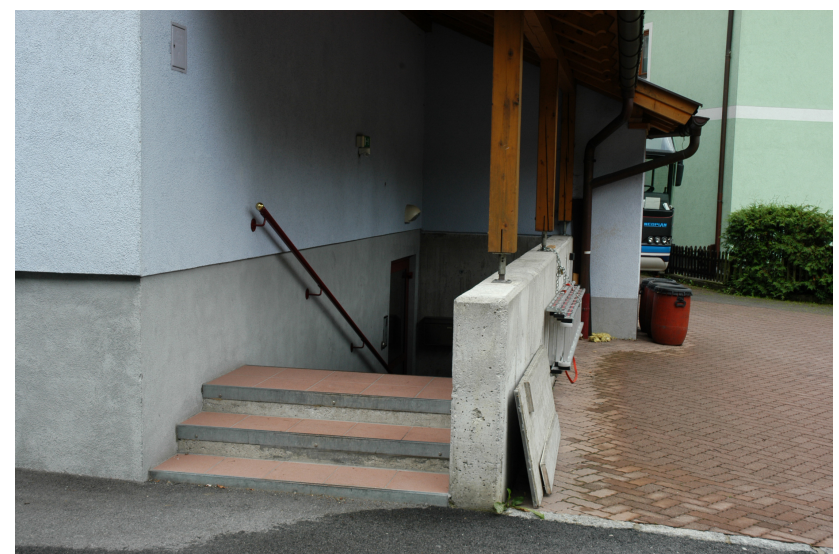

Fig. 10. New building and upgrade: Enhancement (raising) of basement stairs above flood level.

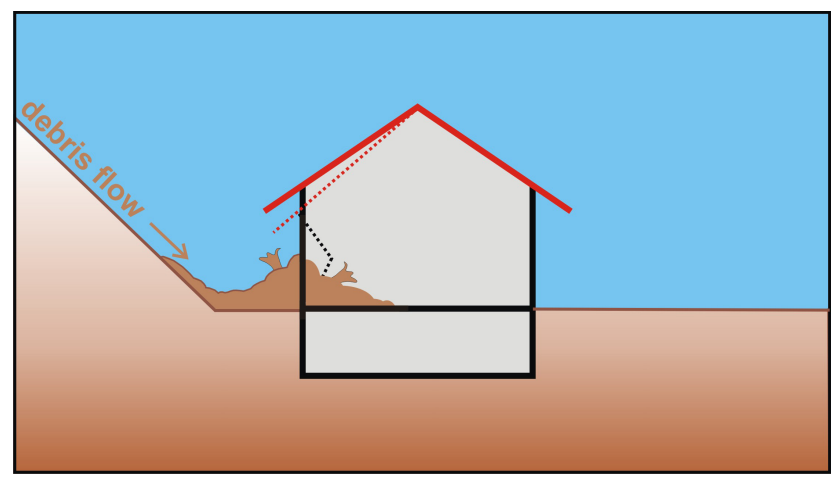

Fig. 11. Damage patterns due to debris flows.

\subsection{Catalogue of local structural measures - debris flow}

Due to pressure and friction, debris flows can induce high forces to buildings. Impacts originating from the dynamic or static load of debris flow material and transported solids such as boulders endanger the stability of the building (Fig. 11), apart from the possible intrusion of debris flow material through the building openings which might cause damage to the interior of the building. As shown in Fig. 12, several local structural measures are possible. Considering the catalogue of local structural measures to protect buildings against debris flows, selected examples of protection measures such as deflection walls and splitting wedges are presented in Figs. 13 and 14.

\subsection{Catalogue of local structural measures - land slide}

Impacts originating from the dynamic or static load of sliding material endanger the stability of the building (see Fig. 15), in particular with respect to translational slumps. Several local structural measures can be implemented, the most popular are described in Fig. 16. Considering the catalogue of local structural measures to protect buildings against land 


\begin{tabular}{|c|c|c|c|c|}
\hline Relevant impact & Objective & Local structural measure & 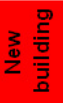 & 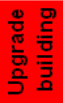 \\
\hline \multirow{9}{*}{$\begin{array}{l}\text { Endangering the stability } \\
\text { of the exposed object }\end{array}$} & \multirow{2}{*}{ Prevention of general damages } & Elevated construction & $\ddot{*}$ & \\
\hline & & Wedge-shaped floor plan & $\ddot{*}$ & \\
\hline & \multirow{6}{*}{$\begin{array}{l}\text { Prevention of damage to outwalls } \\
\text { (measures at and around the building) }\end{array}$} & Retention dam & $\ddot{*}$ & $\ddot{-}$ \\
\hline & & Deflection dam/wall & $\ddot{*}$ & $\ddot{-}$ \\
\hline & & Splitting wedge for buildings and pylons & $\ddot{*}$ & $\ddot{-}$ \\
\hline & & Strengthening of exposed walls (reinforced concrete) & $\ddot{\sim}$ & \\
\hline & & Reinforced facing formwork & $\ddot{*}$ & $\ddot{*}$ \\
\hline & & Stand-alone pillars out of reinforced concrete & $\ddot{\sim}$ & $\ddot{-}$ \\
\hline & Prevention of damage on intermediate ceilings & Strengthening of intermediate ceilings & $\ddot{\sim}$ & 9 \\
\hline \multirow{3}{*}{ Intrusion of debris material } & \multirow{3}{*}{$\begin{array}{l}\text { Prevention of damage due to } \\
\text { mechanical demolition and contamination }\end{array}$} & No openings in exposed walls & $\ddot{*}$ & $\ddot{-}$ \\
\hline & & Small windows (located far above ground level) & $\ddot{*}$ & $\ddot{-}$ \\
\hline & & Impact protection for windows (massive shutter) & $\ddot{*}$ & $\ddot{*}$ \\
\hline & & Concept of internal and external use of the object & $\ddot{*}$ & $\ddot{*}$ \\
\hline & & Combination of protection measures & $\ddot{\sim}$ & $\ddot{*}$ \\
\hline & & \multicolumn{2}{|l|}{ Constructive easily feasible } & $\ddot{*}$ \\
\hline & & \multicolumn{2}{|l|}{ Constructive hardly feasible } & $\ddot{-}$ \\
\hline & & \multicolumn{2}{|l|}{ Constructive not feasible } & \\
\hline
\end{tabular}

Fig. 12. Local structural measures for new buildings as well as for an upgrade of existing objects with respect to possible impacts of debris flows.

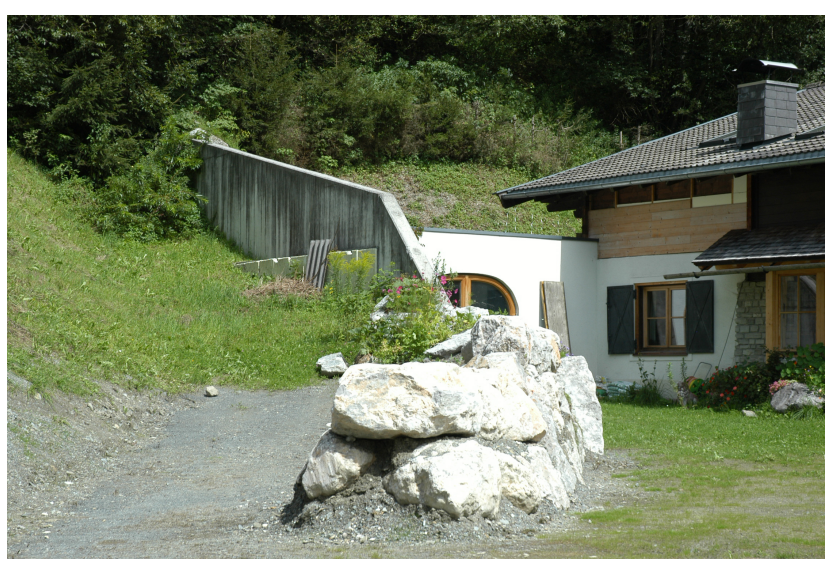

Fig. 13. New building and upgrade: Deflection wall and dam.

slides, selected examples of protection measures such as soil bio-engineering and soil-nailing are presented in Figs. 1718. Moreover, the stabilisation of sliding masses is strongly supported by an efficient drainage system installed in the subsurface layers (Fig. 19).

\subsection{Catalogue of local structural measures - rock fall}

Impacts originating from the dynamic load of rolling, bouncing or falling rocks obviously jeopardise the stability of the building as well as the interior of the building (Fig. 20). Several local structural measures are possible, the most promising are described in Fig. 21. Considering the catalogue of local structural measures to protect buildings against rock fall processes, selected examples of protection measures include

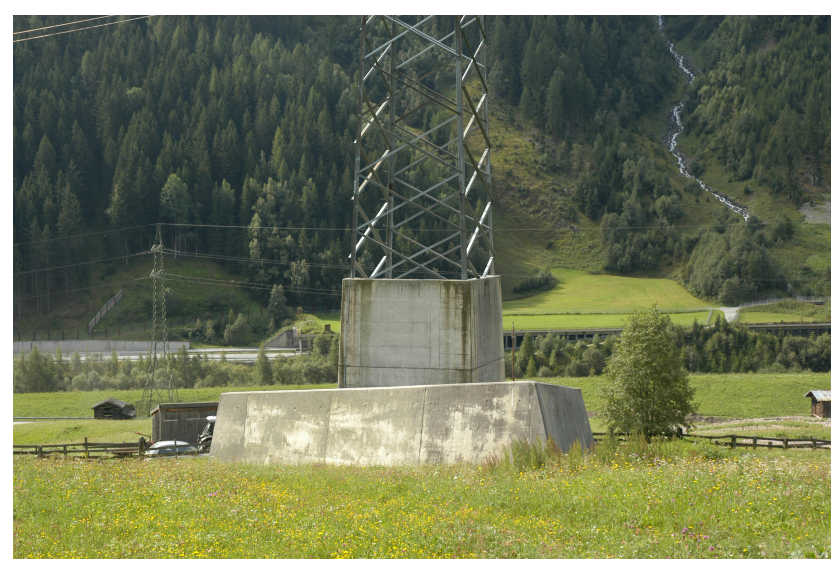

Fig. 14. New building (and upgrade): Deflection wall and splitting wedge.

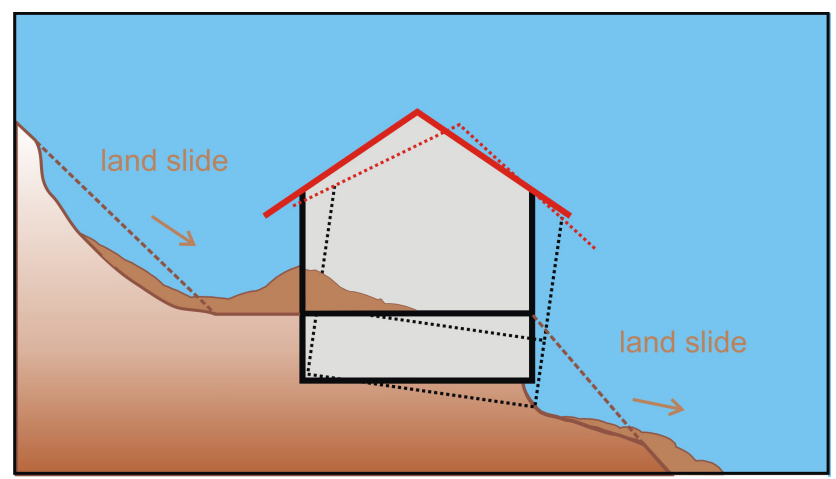

Fig. 15. Damage patterns due to land slides. 


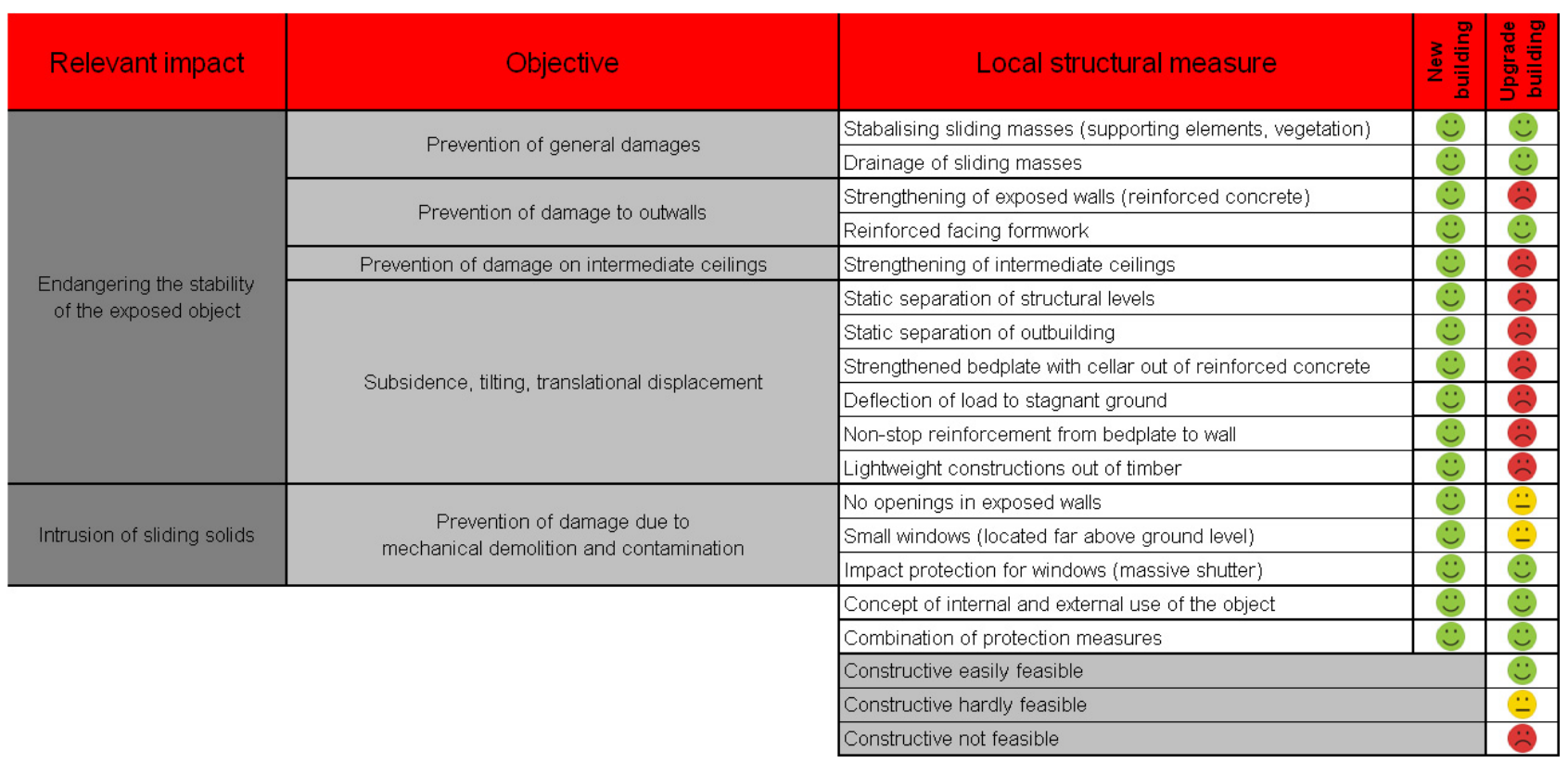

Fig. 16. Local structural measures for new buildings as well as for an upgrade of existing objects with respect to possible impacts of land slides.

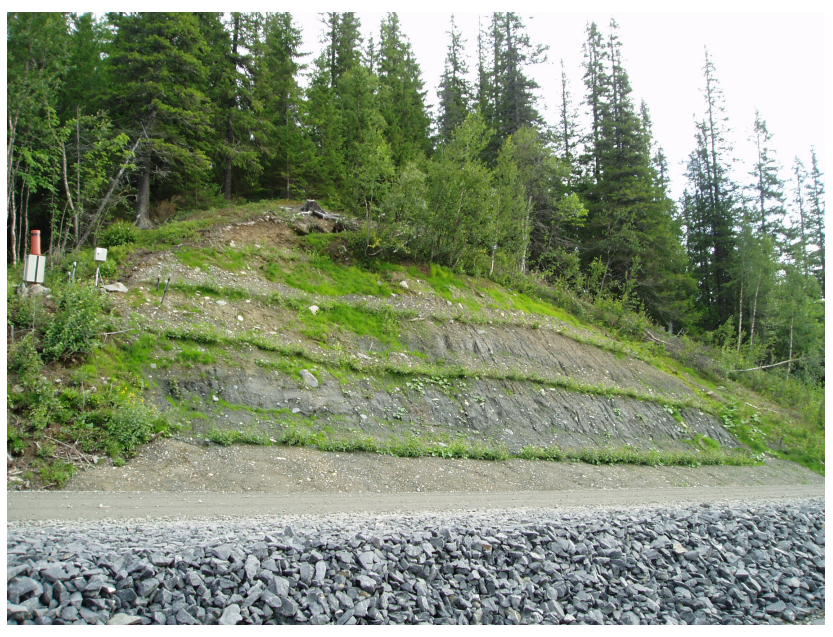

Fig. 17. New building and upgrade: Soil bio-engineering measures to stabilise unsteady slopes (courtesy of: Rankka, 2005).

earth-filled dams on the hillside of objects to dissipate the kinetic energy (Fig. 22) and strengthened outer walls without any windows (Fig. 23). While earth-filled dams are relatively space consuming, they are considerably efficient in particular if they are combined with net barriers (Fig. 24).

\subsection{Catalogue of local structural measures - avalanche}

Avalanches with their dense and powder fraction can affect buildings with high pressures and pulls to walls and roofs. Impacts originating from the dynamic or static load of snow

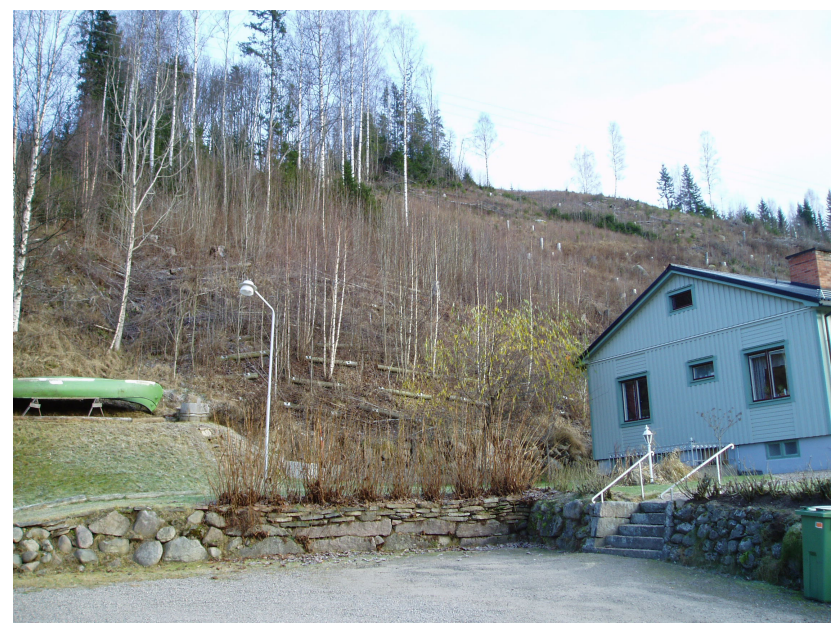

Fig. 18. New building and upgrade: Soil nailing measures to stabilise unsteady slopes (courtesy of: Rankka, 2005).

and transported solids jeopardise the stability of the building (Fig. 25). An additional frequently observed impact is the intrusion of snow through the building openings which result in remarkable damage to the interior of the buildings. Local structural measures are widely used in European mountain regions, the most promising are described in Fig. 26. Considering the catalogue of local structural measures to protect buildings against avalanches, selected examples of protection measures such as deflection dams and splitting facilities (Fig. 27), and roof terraces to integrate the building into the surface of the slope are presented (Fig. 28). Earth-filled dams 


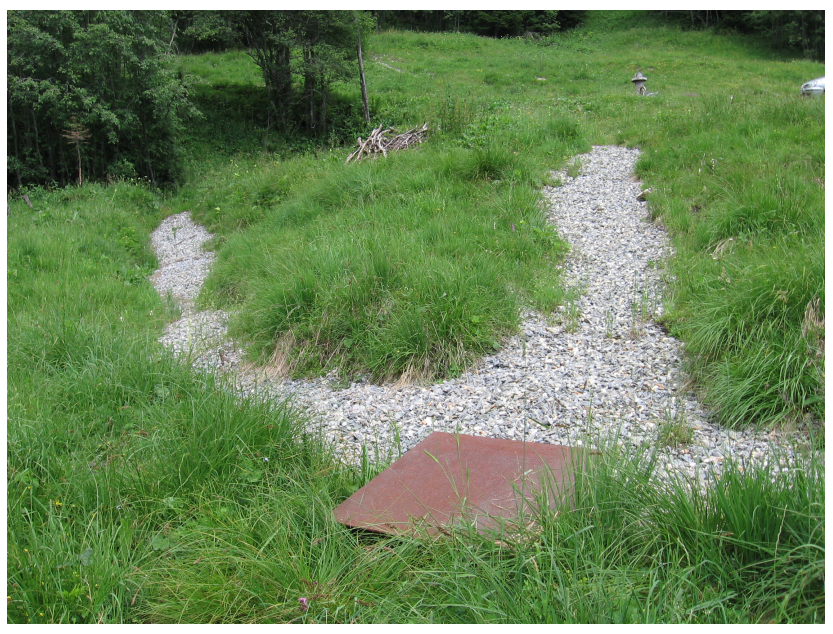

Fig. 19. Enclosing structures: Drainage system to stabilise the sliding layers of the slope.

have a long tradition tracing back to mediaeval times and are very efficient, while porched walls (Fig. 29) and reinforced shutters (Fig. 30) are only used since the 1960s.

\section{Conclusions}

Effective local structural measures are the result of systematic hazard analyses and aim at the reduction of vulnerability of values at risk located in the accumulation areas of hazard processes. The importance of local structural measures is related to the concept of conventional mitigation on the one hand and the implementation of land-use planning on the other hand. Consequently, the concept of local protection should be embedded within the framework of integral risk management strategies.

Considering different mass movement processes and their impacts on the built environment, multiple solutions for the protection of new buildings and the upgrade of existing inventory exist. Planned early, expenditures for the implementation of local structural measures are comparatively low related to the total cost of the planned construction.

Recent studies related to torrential hazards in Austria (Fuchs et al., 2007b) and Switzerland (Romang, 2004) suggested a considerable decrease in vulnerability, if local structural protection is implemented. However, until now it is hardly possible to quantify the risk-minimising effects of local structural measures. Hence, further studies have to be carried out in order to assess these effects and their consequences for future enhancement of risk minimising efforts with respect to buildings and infrastructure facilities.

Apart from these overall goals, there are specific needs for an improvement of the level of information for affected people, legal regulations and risk transfer mechanisms in Austria as well as other European mountain regions. These needs

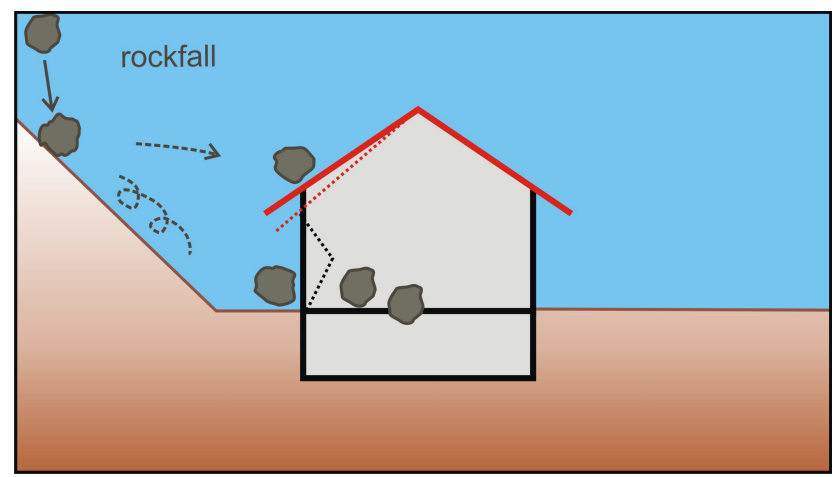

Fig. 20. Damage patterns due to rock falls.

would not only result in an increased risk awareness of people concerned, but also in an enhanced enforceability of necessary legal regulations, above all building codes. As a result, the individual responsibility could be strengthened and the society will be enabled to alternatively use (increasingly scarce) public funds in a more cost-efficient way.

\subsection{Information}

It has been widely accepted that people who experienced natural hazards and their impacts are willing and able to reduce their individual susceptibility considerable (e.g., Smith, 1981; Wind et al., 1999). However, since half-life of knowledge is very short, information about natural hazards and their damage potential to exposed values at risk should be repeatedly provided by communities, e.g. by regular informative meetings at community level. Such meetings should also include technical information on underlying assumptions made during the risk assessment procedure, such as the concept of probability, ranges and uncertainties associated with design events, and residual risk. Furthermore, the potential of local structural measures should be clearly stressed, as well as their comparatively low costs with respect to potential losses. This list is not exhaustive; above all, people have to know where to obtain professional help in planning local structural measures.

\subsection{Legislation}

According to a decision of the supreme court of the Republic of Austria, hazard maps feature the character of a qualified expertise rather than a legal basis for land-use planning activities (Hattenberger, 2006; Kanonier, 2006), and thus have no obligating effect for builders and home-owners concerning imposed restrictions (building codes). Hence, hazard maps should become an obligatory part of land-use planning activities by using standardised (legal) procedures and terms to minimise the scope of interpretation of restrictions due to these maps (Schremmer et al., 2005). However, these requirements might not be consistent to the strongly federal 


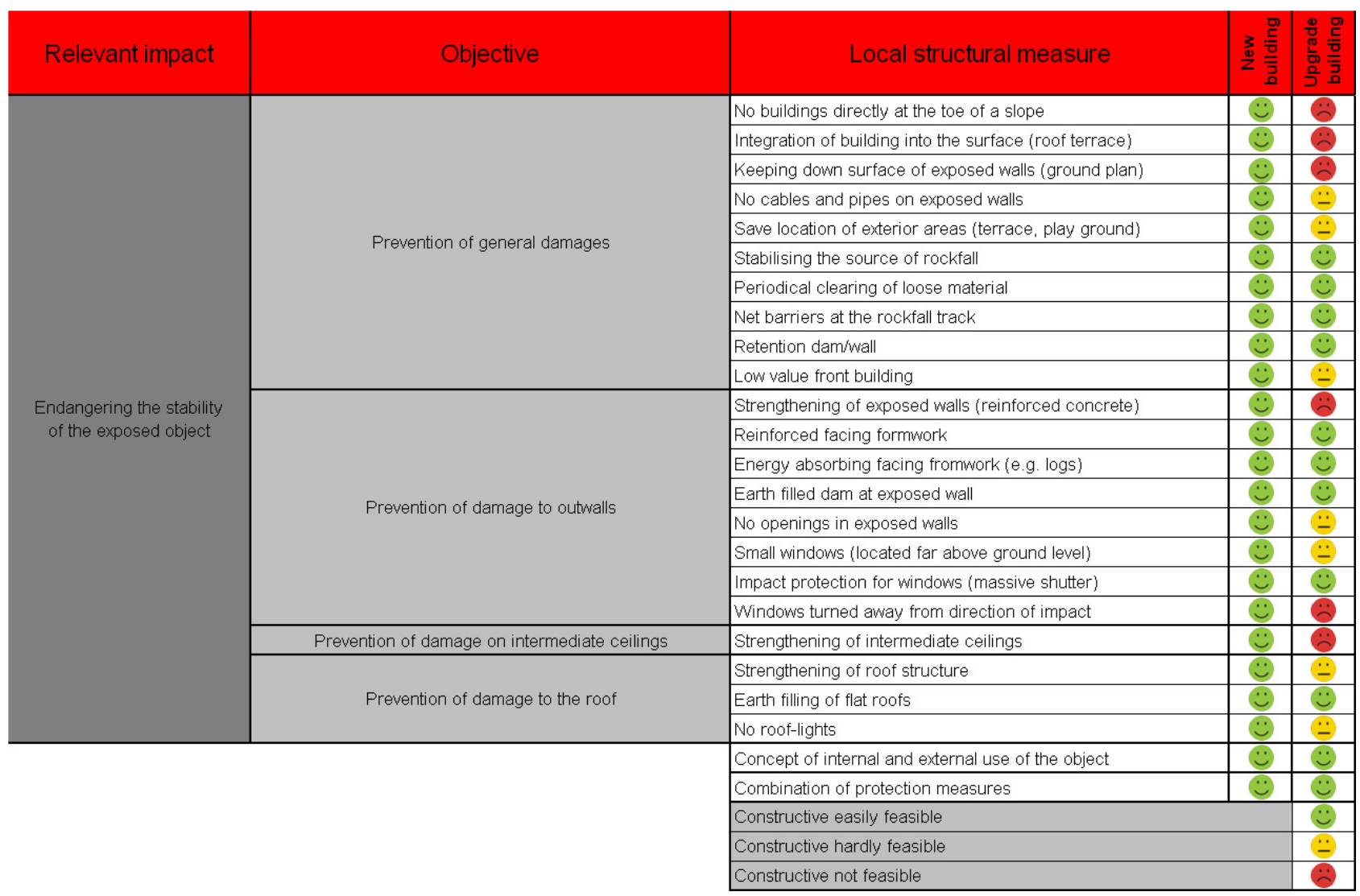

Fig. 21. Local structural measures for new buildings as well as for an upgrade of existing objects with respect to possible impacts of rock falls.

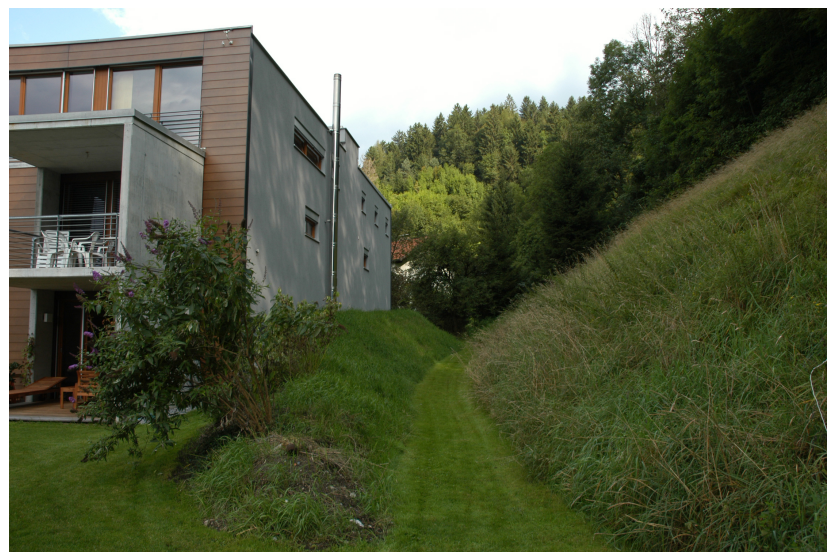

Fig. 22. New building and upgrade: Earth-filled dam for energy dissipation of falling rocks.

organisation of Austria's governmental structure. In each individual federal state, different building acts exist, which makes a national standardisation of legal prescriptions difficult. Furthermore, hazard mapping is a national affair, while building laws are a matter of federal states (Hattenberger,

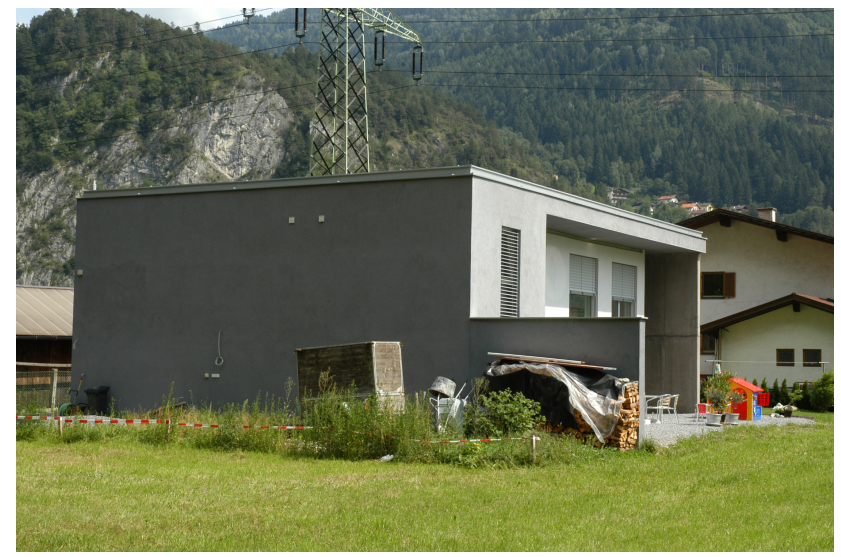

Fig. 23. New building: Strengthened front wall without windows.

2006). Compulsory building codes implemented on the national level for objects in exposed areas should be the minimum standard to be achieved in the future. With respect to a reduction of risk, exceptional building permits in red hazard zones have to be considerably reduced. Compulsory building permits should be prescribed even for small construction 


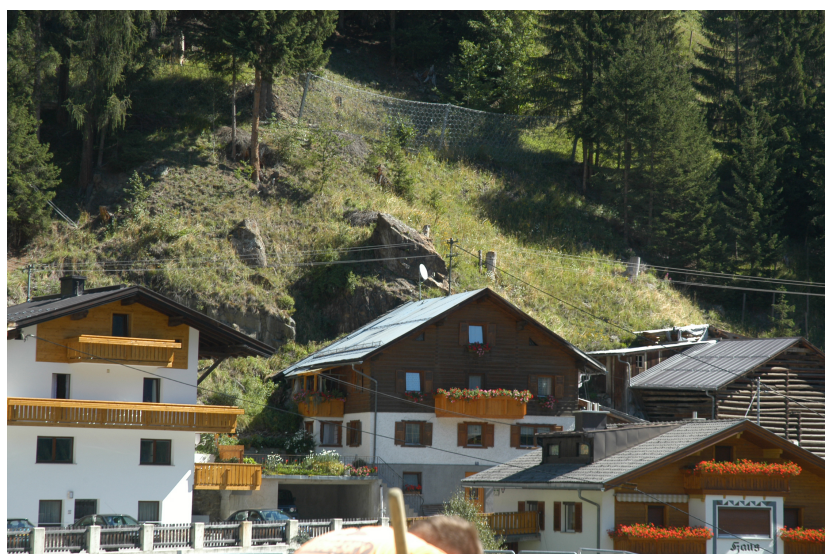

Fig. 24. Enclosing structures: Net barrier to protect buildings against rock fall.

projects, and should be accompanied by a compulsory final technical acceptance of completed buildings to receive the permission of use.

\subsection{Risk transfer}

It has been outlined in Sect. 2 that natural hazards are not yet subject to compulsory insurance in Austria. Nevertheless, concepts of obligatory insurance evolved in other countries affected by natural hazards, and succeeded in a considerable risk reduction (Ungern-Sternberg, 2004; Fleischhauer et al., 2006). Apart from the ongoing discussion on a possible implementation of such an insurance in Austria (Fuchs, 2007, personal communication), reduced premiums for implemented local structural measures could be a possible incentive to increase acceptability of individual precaution. Furthermore, a positive consideration of both, local structural measures and private insurances in case of necessary compensations by the catastrophe fund would be desirable (The current situation in Austria acts the opposite way: Compensations paid out by privately effected insurances are subtracted from grant aids by the catastrophe fund; Prettenthaler and Vetters, 2005). In order to foster such incentives, local structural measures would also be promoted if reduced bank credits for construction were available.

\section{Appendix A}

\section{Hazard zone mapping in Austria}

In Austria, the methodology for delimiting hazard zones is regulated by a national legal act (Republik Österreich, 1975) and an associated decree (Republik Österreich, 1976). The implementation of these regulations is assigned to the Federal Ministry of Agriculture, Forestry, Environment and Water Management (BMLFUW) and administrated by the gov-

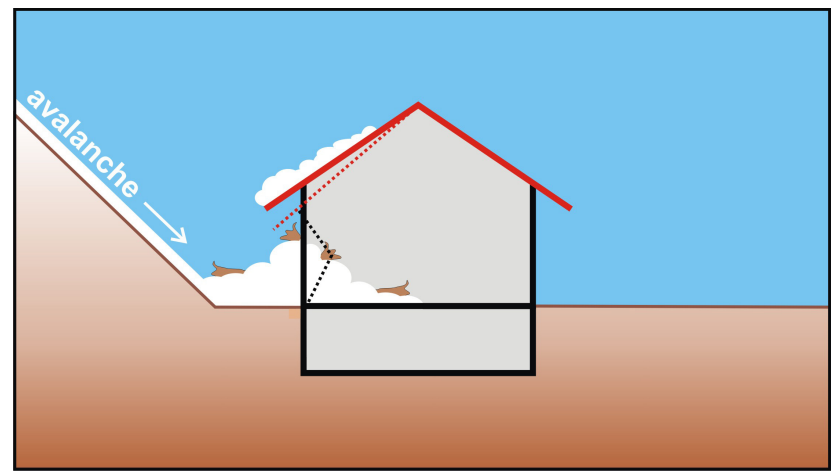

Fig. 25. Damage patterns due to avalanches.

ernmental departments of the Austrian Service for Torrent and Avalanche Control (WLV) ${ }^{1}$ and the Federal Water Engineering Administration.

The Forest Act $(\S 8 \mathrm{~b})$ of 1975 prescribes the delimitation of hazard zones in catchment areas susceptible to natural hazards such as torrential floods or avalanches (Forest Act § 99) and areas reserved for mitigation measures. In $\S 11$, the compilation of hazard maps and the involvement of communes and population are regularised. The contents and designs of these maps are specified by the decree ${ }^{2}$ associated to the Forest Act (Republik Österreich, 1976). According to $\S 5$ (2) of the Decree on Hazard Zoning, all available data and information on natural hazards as well as interactions between individual hazard processes have to be considered during the compilation of hazard maps. Furthermore, interferences with the human environment, such as infrastructure facilities and settlements have to be taken into account.

Hazard maps are usually based on the area of an individual community, and should be compiled in a reproducible manner to allow for validation during the approval process by the Federal Ministry of Agriculture, Forestry, Environment and Water Management.

Hazard maps are based on a design event with a return period of 150 years, and an event occurring more frequent with a return period of 10 years (Republik Österreich, 1976). In $\S 6$ of the Decree on Hazard Zoning ${ }^{3}$, the criteria for delimitation of hazard zones is prescribed. According to these prescriptions, red hazard zones indicate those areas where the permanent utilisation for settlement and traffic purposes is not possible or only possible with extraordinary efforts for mitigation measures. Yellow hazard zones indicate those areas where a permanent utilisation for settlement and traffic purposes is impaired by hazard processes. Furthermore, specific other areas have to be displayed in the hazard maps:

\footnotetext{
${ }^{1}$ ForstG $\S 11$ Abs. 1

${ }^{2}$ Decree of the Federal Minister; Verordnung des Bundesministers für Land- und Forstwirtschaft vom 30. Juli 1976 über die Gefahrenzonenpläne (GefahrenzonenplanVO), BGB1 1976/436

${ }^{3}$ GefahrenzonenplanVO $§ 6$
} 


\begin{tabular}{|c|c|c|c|c|}
\hline Relevant impact & Objective & Local structural measure & 旁竞 & 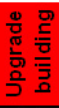 \\
\hline \multirow{16}{*}{$\begin{array}{l}\text { Endangering the stability } \\
\text { of the exposed object }\end{array}$} & \multirow{4}{*}{ Prevention of general damages } & Arrangement of buildings in a line (parallel to flow direction) & $\because$ & \\
\hline & & Integration of building into the surface (roof terrace) & $\ddot{*}$ & \\
\hline & & Keeping down absolute height of building (exposed surface) & $\ddot{*}$ & \\
\hline & & Wedge-shaped floor plan & $\ddot{Y}$ & \\
\hline & \multirow{8}{*}{$\begin{array}{l}\text { Prevention of damage to outwalls } \\
\text { (measures at and around the building) }\end{array}$} & Measures against snow gliding (ground pegs) & $\ddot{*}$ & $\ddot{*}$ \\
\hline & & Retention dam & $\ddot{*}$ & $\ddot{-}$ \\
\hline & & Deflection dam/wall & $\ddot{*}$ & $\ddot{-}$ \\
\hline & & Low value front building & $\ddot{*}$ & $\ddot{-}$ \\
\hline & & Splitting wedge for buildings and pylons & $\ddot{*}$ & $\ddot{-}$ \\
\hline & & Earth filled dam at exposed wall & $\ddot{*}$ & $\ddot{-}$ \\
\hline & & Strengthening of exposed walls (reinforced concrete) & $\ddot{*}$ & \\
\hline & & Reinforced facing formwork & $\ddot{*}$ & $\ddot{*}$ \\
\hline & \multirow{3}{*}{ Prevention of damage to the roof } & Strengthening of roof structure & $\ddot{*}$ & $\ddot{-}$ \\
\hline & & Stand-alone pillars out of reinforced concrete & $\ddot{*}$ & $\ddot{-}$ \\
\hline & & Short eaves respective fixed roofs (pull) & $\ddot{\sim}$ & $\ddot{-}$ \\
\hline & $\begin{array}{l}\text { Prevention of damage on intermediate ceilings } \\
\text { and snow covered buildings }\end{array}$ & Strengthening of intermediate ceilings & $\ddot{\theta}$ & \\
\hline \multirow{10}{*}{ Intrusion of snow } & \multirow{10}{*}{$\begin{array}{l}\text { Prevention of damage due to } \\
\text { mechanical demolition }\end{array}$} & No openings in exposed walls & $\ddot{*}$ & $\ddot{-}$ \\
\hline & & Protection of entrance by a front building & $\ddot{*}$ & $\ddot{-}$ \\
\hline & & Small windows (located far above ground level) & $\ddot{*}$ & $\ddot{-}$ \\
\hline & & Windows turned away from direction of impact & $\ddot{*}$ & 9 \\
\hline & & $\begin{array}{l}\text { Window/door frames mounted on metallic frame } \\
\text { (no polyurethane foam) }\end{array}$ & $\mathcal{Y}$ & $\ddot{-}$ \\
\hline & & Avalanche resistant windows with rugged fittings & $\ddot{*}$ & $\ddot{*}$ \\
\hline & & Attaching doors and windows from the outside & $\ddot{*}$ & $\ddot{-}$ \\
\hline & & Impact protection for windows (massive shutter) & $\ddot{*}$ & $\ddot{*}$ \\
\hline & & Mounting the shutters on the wall (not on the frame) & $\ddot{*}$ & $\ddot{*}$ \\
\hline & & Countersinking of shutters in wall (shearing effect) & $\ddot{*}$ & $\ddot{-}$ \\
\hline & & Concept of internal and external use of the object & $\ddot{*}$ & $\ddot{Y}$ \\
\hline & & Combination of protection measures & $\ddot{\sim}$ & $\ddot{*}$ \\
\hline & & \multicolumn{2}{|l|}{ Constructive easily feasible } & $\ddot{*}$ \\
\hline & & \multicolumn{2}{|l|}{ Constructive hardly feasible } & $\ddot{-}$ \\
\hline & & \multicolumn{2}{|l|}{ Constructive not feasible } & \\
\hline
\end{tabular}

Fig. 26. Local structural measures for new buildings as well as for an upgrade of existing objects with respect to possible impacts of avalanches.

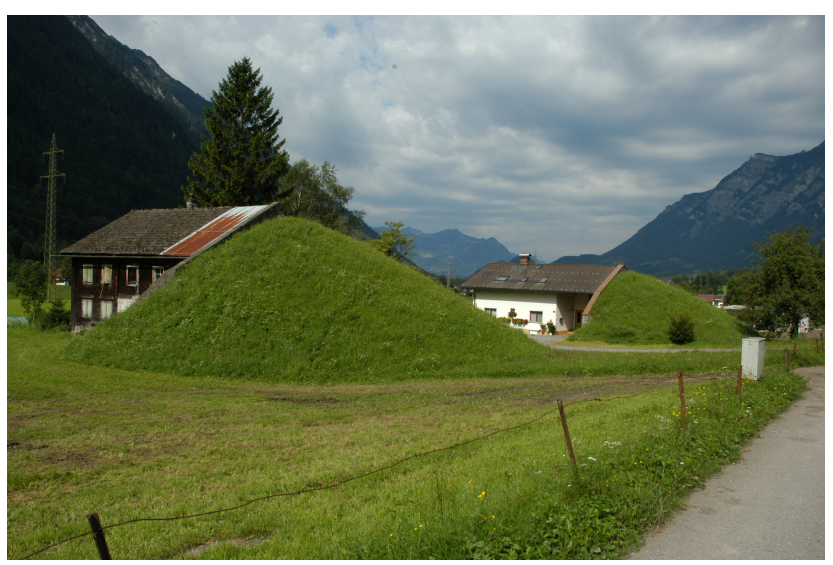

Fig. 27. New building and upgrade: Earth-filled dams as deflection and splitting facilities.

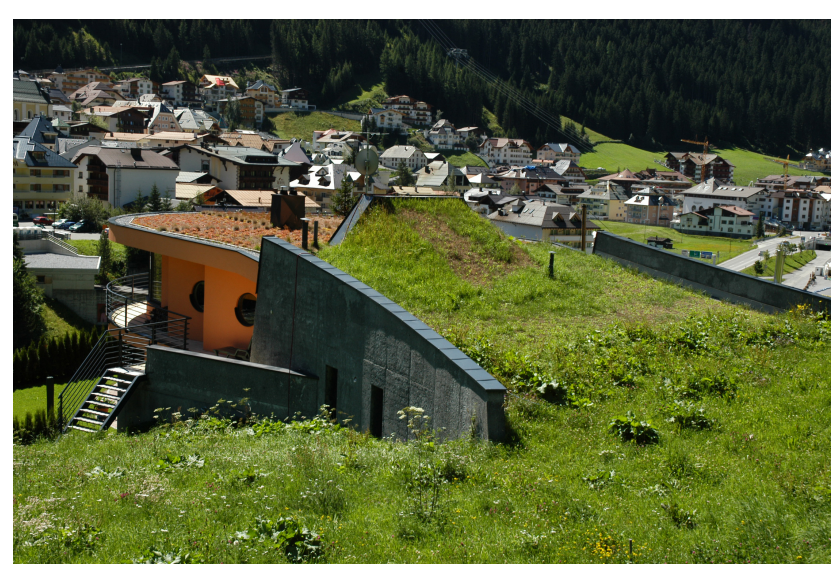

Fig. 28. New building: Roof terrace to integrate the building into the surface of the slope. 


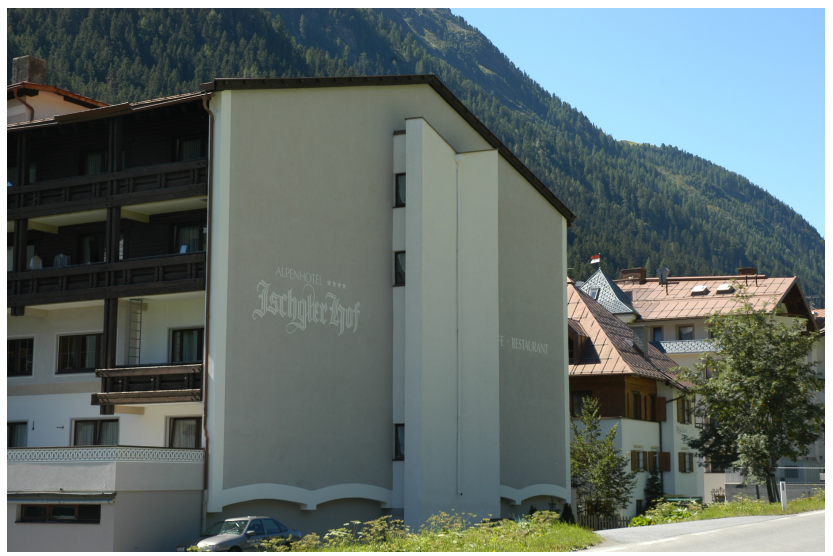

Fig. 29. New building: Protection of windows by porched walls.

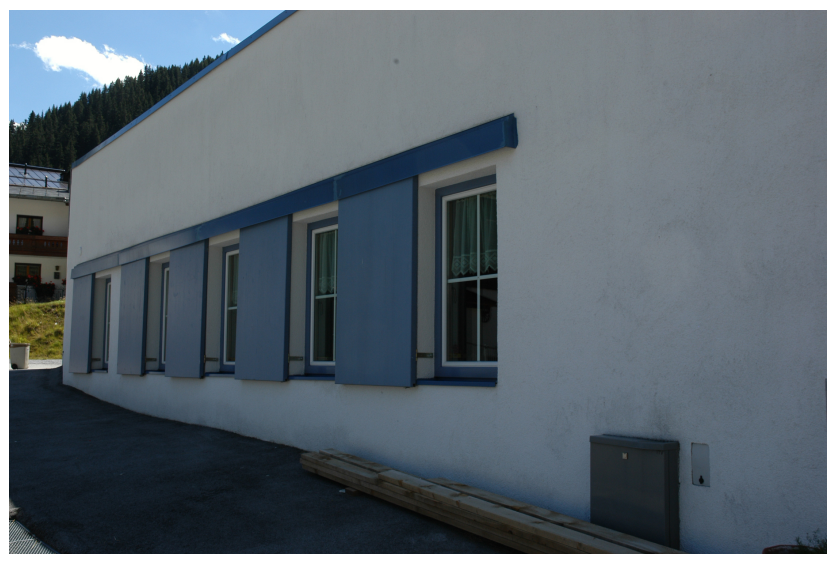

Fig. 30. New building and upgrade: Window shutters to prevent intrusion of snow.

(1) Blue colours mark areas to be provided for future mitigation measures, (2) brown colours indicate areas affected by land slides and rock fall and (3) purple colours indicate areas that can be used as protection due to their natural properties, such as protection forests or natural retention basins.

Acknowledgements. The underlying studies were partly funded by the European Commission (Contract 018412) within the IRASMOS project (Integral Risk Management of Extremely Rapid Mass Movements). The authors would like to express their sincere thanks to the IRASMOS consortium for stimulating discussions of the presented results. The authors wish to kindly acknowledge S. Fuchs, University of Natural Resources and Applied Life Sciences, for valuable comments on an earlier version of this paper. Alfred Strauss provided insightful inputs in the development of Fig. 4. Furthermore, the authors are grateful to W. Edwards and R. Ristić for reviewing the manuscript.

Edited by: M. Keiler, S. Fuchs, and T. Glade Reviewed by: W. Edwards and R. Ristić

\section{References}

Aulitzky, H.: Der Enterbach (Inzing in Tirol) am 26. Juli 1969, Versuch einer Analyse eines Murganges als Grundlage für die Neuerstellung einer zerstörten Wildbachverbauung, Wildbachund Lawinenverbau, 34. Jahrgang, 1970.

Belský, J. and Jařabáč, M.: Experiences from the torrent control in the Czech Republic between 1884-2003, Internationales Symposion INTERPRAEVENT 2004 - Riva/Trient, Tagungspublikation, Band 3, 13-18, 2004.

BEV (Bundesamt für Eich- und Vermessungswesen): Daten der Regionalinformation der Grundstücksdatenbank 1999-2004, http://www.bev.gv.at/, 2004.

Berg, M., Erdmann, G., Hofmann, M., Jaggy, M., Scheringer, M., and Seiler, H. (Eds.): Was ist ein Schaden? Polyprojekt Risiko und Sicherheit - Dokumente Nr. 2, Zürich, vdf. 1994.

BMLFUW (Bundesministerium für Land- und Forstwirtschaft, Umwelt und Wasserwirtschaft): Flood protection in Austria. Federal Ministry of Agriculture, Forestry, Environment and Water Management, 2006.

Borter, P.: Risikoanalyse bei gravitativen Naturgefahren, Bern, Bundesamt für Umwelt, Wald und Landschaft, 1999.

Egli, T.: Gefahrenkarten für die Bauvorsorge und Notfallplanung. Workshop Vorbeugender Hochwasserschutz auf kommunaler Ebene, 13.-14.12.2000 Dresden, Institut für ökologische Raumentwicklung, Umweltbundesamt Berlin, 2000a.

Egli, T.: Risikobewertung: Aufgabe von Sicherheitsbehörden und Legitimation von Betroffenen. Internationales Symposium INTERPRAEVENT 2000 - Villach/Österreich, Tagungspublikation, Band 2, 241-251, 2000b.

Egli, T.: Hochwasserschutz durch nachhaltiges Schadenpotenzialmanagement. Internationales Symposium 2002 in Zürich: Moderne Methoden und Konzepte im Wasserbau, Versuchsanstalt für Wasserbau, Hydrologie und Glaziologie der ETH Zürich und dem Schweizerischen Wasserwirtschaftsbund, 2002a.

Egli, T.: Hochwasservorsorge - Maßnahmen und ihre Wirksamkeit, Hrsg.: Internationale Kommission zum Schutz des Rheins, 2002b.

Embleton-Hamann, C.: Naturgefahren in Österreich. Ursachen, Verbreitung, Schäden und Schutzmaßnahmen, Mitteilungen der Österreichischen Geographischen Gesellschaft 139, 197-230, 1997.

Fell, R.: Landslide risk assessment and acceptable risk, Canadian Geotechnical Journal, 31, 261-272, 1994.

Fell, R. and Hartford, D.: Landslide Risk Management, edited by: Cruden, D. and Fell, R., Landslide Risk Assessment, Balkema, Rotterdam, 51-109, 1997.

FEMA (Federal Emergency Management Agency): Repairing your flooded home, FEMA Publications, Washington, DC, 1998.

Fleischhauer, M., Greiving, S., and Wanczura, S.: Natural hazards and spatial planning in Europe, Dortmunder Vertrieb für Bauund Planungsliteratur. Dortmund, 2006.

Fuchs, S. and Bründl, M.: Damage potential and losses resulting from snow avalanches in settlements of the canton of Grisons, Switzerland, Nat. Hazards, 34(1), 53-69, 2005.

Fuchs, S., Thöni, M., McAlpin, M. C., Gruber, U., and Bründl, M.: Avalanche hazard mitigation strategies assessed by cost effectiveness analyses and cost benefit analyses - evidence from Davos, Switzerland, Nat. Hazards, 41(1), 113-129, 2007 a.

Fuchs, S., Heiss, K., and Hübl, J.: Towards an empirical vulnerabil- 
ity function for use in debris flow risk assessment, Nat. Hazards Earth Syst. Sci., 7, 495-506, 2007b.

Grothmann, T. and Reusswig, F.: People at risk of flooding: Why some residents take precautionary action while others do not, Nat. Hazards, 38, 101-120, 2006.

Habersack, H. M., Petraschek, A., and Bürgel, J.: Analyse der Hochwasserereignisse vom August 2002 - FloodRisk, Synthesebericht, BMLFUW, UBA, Wien, 2004.

Hattenberger, D.: Naturgefahren und öffentliches Recht, in: Recht im Naturgefahrenmanagement, edited by: Fuchs, S., Khakzadeh, L., and Weber, K., Studien-Verlag, Innsbruck, 67-91, 2006.

Hooijer, A., Klijn, F., Pedroli, G. B. M., and Van Os, A. G.: Towards sustainable flood risk management in the Rhine and Meuse river basins: Synopsis of the findings of irma-sponge, River Res. Appl., 20, 343-357, 2004.

Hübl, J. and Steinwendtner, H.: Debris flow hazard assessment and risk mitigation, in: Felsbau - Rock and Soil Engineering, 1/2000, 17-23, 2000.

Hübl, J. and Fiebiger, G.: Debris-flow mitigation measures, in: Debris-Flow Hazards and Related Phenomena, edited by: Jakob, M. and Hungr, O., Berlin, Springer, XLII, 445-487, 2005.

IBHS (Institute for Business \& Home Safety): The benefits of statewide building codes, Natural Hazard Mitigation Insights, Institute for Business \& Home Safety, Tampa, 2005.

Ita, D. and Giller, J.: Grundlagen der Sicherheitsvorsorge. Das staatliche Krisen- und Katastrophenschutzmanagement in Österreich, in: Katastrophen in Natur und Umwelt. Wissenschaft und Umwelt Interdisziplinär 10. Forum Österreichischer Wissenschaftler für Umweltschutz, Wien, 2006.

Jóhannesson, T. and Arnalds: Accidents and Economic Damage due to Snow Avalanches and Landslides in Iceland, Jökull, 50, 81-94, 2001.

Kanonier, A.: Raumplanungsrechtliche Regelungen als Teil des Naturgefahrenmanagements, in: Recht im Naturgefahrenmanagement, edited by: Fuchs, S. Khakzadeh, L., Weber K., StudienVerlag, Innsbruck, 123-153, 2006.

Kimmerle, R.: Schadenempfindlichkeit von Gebäuden gegenüber Wildbachgefahren. Diplomarbeit am Geografischen Institut der Universität Bern, Unveröffentlicht, 2002.

Kreibich, H., Thieken, A. H., Petrow, T., Müller, M., and Merz, B.: Flood loss reduction of private households due to building precautionary measures - lessons learned from the Elbe flood in August 2002, Nat. Hazards Earth Syst. Sci., 5, 117-126, 2005, http://www.nat-hazards-earth-syst-sci.net/5/117/2005/.

Länger, E.: Der forsttechnische Dienst für Wildbach- und Lawinenverbauung in Österreich und seine Tätigkeit seit der Gründung im Jahre 1884 - die Grundlagen für die Aufgabenerfüllung der Dienststellen der Wildbach- und Lawinenverbauung im Bereich der heutigen Republik Österreich, sowie die allgemeine Entwicklung der Tätigkeiten der Dienststellen, insbesondere im Bundesland Kärnten, Dissertation an der Universität für Bodenkultur Wien, 2003 (unpublished).

Länger, E.: A history of hazard-zone mapping development in Austria. Journal of Torrents, Avalanche, Landslide and Rock Fall Engineering, 152, 13-24, 2005.

Leitgeb, M. and Rudolf-Miklau, F.: Risk and disaster management in natural hazards as floods, debris flows, land slides, rock fall and avalanches in Austria, Internationales Symposion INTERPRAEVENT 2004 - Riva/Trient, Tagungspublikation, Band 4,
125-134, 2004.

Luzian, R.: Lawinenschäden in Österreich in der Periode von 1967/68 bis 1992/93, Internationales Symposion INTERPRAEVENT 2000 - Villach, Tagungspublikation, Band 1, 437 450, 2000.

Mayer, R.: EU-Wasserrahmenrichtlinie - Neue Perspektiven für die Wildbach- und Lawinenverbauung in Österreich. Internationales Symposion INTERPRAEVENT 2004 - Riva/Trient, Tagungspublikation, Band 4, 161-169, 2004.

Mileti, D. and Myers, M. F.: A bolder course for disaster reduction: imagining a sustainable future, Revista Geofisica, 47, 4158, 1997.

Munich Re: Knowledge series: Topics Geo. Natural catastrophes 2006 - Analyses, assessments, positions, Munich Re Group, München, 2007.

Nöthiger, C., Elsasser, H., Bründl, M., and Ammann, W.: Indirekte Auswirkungen von Naturgefahren auf den Tourismus - Das Beispiel des Lawinenwinters 1999 in der Schweiz, Geographica Helvetica, 2, 91-108, 2002.

Oberndorfer, S., Fuchs, S., Rickenmann, D., and Andrecs, P.: Vulnerabilitätsanalyse und monetäre Schadensbewertung von Wildbachereignissen in Österreich, Wien, Bundesforschungs- und Ausbildungszentrum für Wald, Naturgefahren und Landschaft (BfW), 2007.

Österreichisch-Ungarische Monarchie: Gesetz vom 30. Juni 1884, betreffend Vorkehrungen zur unschädlichen Ableitung von Gebirgswässern, Reichsgesetzblatt für die im Reichsrath vertretenen Königreiche und Länder, Jg. 1870-1918 - Wien, Kaiserl.-königl. Hof- und Staatsdruckerei 1870-1918, 1884.

Patek, M.: Leben mit Naturgefahren; Risikodialog - Naturgefahren erkennen, kommunizieren, akzeptieren. Beitrag zum Workshop des Bayrischen Staatsministeriums für Landesentwicklung und Umweltfragen und der Münchner Rück, 23. Juli 2003, München, 2003.

Prettenthaler, F. and Vetters, N.: Finanzielle Bewältigung von Naturgefahren. Vorschläge zur Reform des österreichischen Modells, InTeReg Working Paper Nr. 21-2005, Joanneum Research Forschungsgesellschaft mbH - Institut für Technologieund Regionalpolitik (InTeReg), ISSN 1810-5807, 2005.

Republik Österreich: Forstgesetz 1975, 1975.

Republik Österreich: Verordnung des Bundesministers für Landund Forstwirtschaft vom 30. Juli 1976 über die Gefahrenzonenpläne, Republik Österreich, 1976.

Romang, H.: Wirksamkeit und Kosten von WildbachSchutzmassnahmen. Arbeitsgemeinschaft Geographica Bernensia G73, Verlag des Geographischen Instituts der Universität Bern, 2004.

Roy, E., Rousselle, J., and Lacroix, J.: Flood Damage Reduction Program (FDRP) in Quebec: Case Study of the Chaudiere River, Nat. Hazards, 28, 387-405, 2003.

Rudolf-Miklau, F. and Patek, M.: Geschiebebewirtschaftung in Wildbacheinzugsgebieten im Einklang mit der EUWasserrahmenrichtlinie, Internationales Symposion INTERPRAEVENT 2004 - Riva/Trient, Tagungspublikation, Band 4, 207-216, 2004.

Schieferer, W.: Abwicklungsfragen im versicherungsrechtlichen Umfeld von Naturgefahren - Zukunftsperspektive der privaten Naturkatastrophen-Vorsorge nach dem Hochwasserereignis vom 23. August 2005, in: Recht im Naturgefahrenmanagement, 
edited by: Fuchs, S., Khakzadeh, L., and Weber, K., StudienVerlag, Innsbruck, 115-122, 2006.

Schmid, F.: Hazard zone map - curse or blessing? Journal of Torrents, Avalanche, Landslide and Rock Fall Engineering, 152, 93 104, 2005.

Schremmer, C., Stanzer, G., and Schönbeck, S.: PROFAN Präventive Raum Ordnung gegen Folgeschäden aus Naturkatastrophen, in: Österreichische Raumordnungskonferenz (ÖROK): Präventiver Umgang mit Naturgefahren in der Raumordnung, Materialienband, Schriftenreihe Nr. 168, Eigenverlag, Wien, 2005

SLF (Ed.): Der Lawinenwinter 1999, Davos, Eidgenössisches Institut für Schnee- und Lawinenforschung, 2000.

Smith, D. I.: Actual and potential flood damage: a case study for urban Lismore, NSW, Australia, Appl. Geogr., 1, 31-39, 1981.

Statistik Austria: Gebäude- und Wohnungszählung 2001 Hauptergebnisse Österreich, Statistik Austria, Bundesanstalt Statistik Österreich, Wien, 2004.

Ungern-Sternberg, T. v.: Efficient Monopolies - The Limits of Competition in the European Property Insurance Market, Oxford Scholarship Monographs, Oxford, 2004.
United Nations: Living with Risk. A Global Review of Disaster Reduction Initiatives, Geneva, United Nations, 2004.

Weinmeister, H. W.: Machbarkeit und Grenzen der WLV Physikalische und ökologische Aspekte, Workshop "Wildbachverbauung und Gewässerökologie", 8.-10. Juni 1994 in Scharfling, O.Ö., Wildbach- und Lawinenverbau, 58. Jahrgang, Heft 126, 47-59, 1994.

Wilhelm, C.: Wirtschaftlichkeit im Lawinenschutz. Methodik und Erhebungen zur Beurteilung von Schutzmaßnahmen mittels quantitativer Risikoanalyse und ökonomischer Bewertung, Mitteilungen Nr. 54, 1997, Eidgenössisches Institut für Schnee- und Lawinenforschung, Davos, 1997.

Wind, H. G., Nierop, T. M., de Blois, C. J., and de Kok, J. L.: Analysis of flood damages from the 1993 and 1995 Meuse floods, Water Resour. Res., 35, 11, 3459-3465, 1999. 